Florida International University FIU Digital Commons

FIU Electronic Theses and Dissertations

University Graduate School

$11-27-2001$

\title{
The effects of defendant account on damage award decisions
}

Tracey Renee Carpenter

Florida International University

DOI: $10.25148 /$ etd.FI14052583

Follow this and additional works at: https://digitalcommons.fiu.edu/etd

Part of the Psychology Commons

\section{Recommended Citation}

Carpenter, Tracey Renee, "The effects of defendant account on damage award decisions" (2001). FIU Electronic Theses and Dissertations. 2053.

https://digitalcommons.fiu.edu/etd/2053

This work is brought to you for free and open access by the University Graduate School at FIU Digital Commons. It has been accepted for inclusion in FIU Electronic Theses and Dissertations by an authorized administrator of FIU Digital Commons. For more information, please contact dcc@fiu.edu. 
FLORIDA INTERNATIONAL UNIVERISTY

Miami, Florida

THE EFFECTS OF DEFENDANT ACCOUNT ON DAMAGE AWARD DECISIONS

A dissertation submitted in partial fulfillment of the requirements for the degree of

DOCTOR OF PHILOSOPHY

in

PSYCHOLOGY

by

Tracey Renee Carpenter 
To: Dean Arthur W. Herriott

College of Arts and Sciences

This dissertation, written by Tracey Renee Carpenter, and entitled The effects of defendant account on damage award decisions, having been approved in respect to style and intellectual content, is referred to you for judgment.

We have read this dissertation and recommend that it be approved.

Janat Fraser Parker

Ronald Fisher

Mary Beth Melchior

Margaret Bull Kovera, Major Professor

Date of Defense: November 27, 2001

The dissertation of Tracey Renee Carpenter is approved.

Dean Arthur W. Herriott College of Arts and Sciences

Dean Douglas Wartzok University Graduate School

Florida International University, 2001 


\section{DEDICATION}

I dedicate this dissertation to God, my family, and my friends. God has guided my path and caught me each time I lost my footing. He has been truly faithful to his promises and has showered me with many blessings. Most importantly, He has given me the love and support of perfect parents and wonderful family members and friends.

My parents have been endlessly understanding and have offered their continuous support, both financial and emotional. Their love and encouragement not only brought me through this, but enabled me to get here in the first place. By believing in me, they allowed me to dream big and they reminded me of those dreams each time that I began to lose sight of them. In them I have what every other person only dreams of having. They are simply amazing people without whom I would be forever lost. My love for them overwhelms me.

Steve, Brian, and Cheryn - you have loved me when I needed love, supported me when I needed support, and made me laugh when I was taking life too seriously. I am proud of each of you and even more proud that you are my brothers and sister. I love you.

Delpha, Christopher, and Nina - you all endured endless hours of my rambling and complaining, for which I am very grateful. I cannot count the number of times that you put your lives on hold to help me with mine. The three of you hung in there with me, with I could not hang in there alone. I will always love you for that. 


\section{ACKNOWLEDGMENTS}

I would like to thank my committee members for all the work they put into this and all the patience they showed me. Dr. Fisher, Dr. Melchior, and Dr. Parker each read long drafts on short notice with no complaints. Their agreeableness made my life much easier.

My major professor, Dr. Kovera, read and revised countless drafts. She endured through all of my mistakes and I would hate to imagine how it all would have turned out had I not had her help. I am abundantly grateful to each of them. 


\section{ABSTRACT OF THE DISSERTATION}

\section{THE EFFECTS OF DEFENDANT ACCOUNT}

\section{ON DAMAGE AWARD DECISIONS}

by

\section{Tracey Renee Carpenter}

Florida International University, 2001

$$
\text { Miami, Florida }
$$

Professor Margaret Bull Kovera, Major Professor

The purpose of this study was to examine whether the manner in which civil defendants account for their behavior influences compensatory and punitive damage awards. Jurors read three civil trial summaries, in which I manipulated injury severity (high vs. low), defendant reprehensibility (high vs. low), defendant status (individual vs. corporate), and account (concession, excuse, justification or refusal) in a factorial design. I also included four control groups in which the defendant stipulated liability. In all other conditions, participants read that a jury had found the defendant negligent. Only defendant reprehensibility influenced punitive awards. Both plaintiff injury and defendant reprehensibility influenced compensatory awards. When individuals offered justifications and when corporations offered excuses, jurors awarded lower compensatory awards against low reprehensibility defendants than against high reprehensibility defendants. Negligence stipulations led to lower damage awards for individuals than for corporations. Additionally, concessions tended to produce lower awards when combined 
with a stipulation of negligence as opposed to a jury decision. These findings support the hypothesis that in cases in which the defendant is clearly negligent, circumstances exist in which stipulating negligence and offering an apologetic account will lead to reduced damage awards decisions. Results indicate that individual and corporate defendants offering justifications and refusals should first consider the reprehensibility of their actions. In a broader realm, findings demonstrate that the manner in which a jury perceives the explanation given by the defendant is dependent upon defendant characteristics and case-specific factors. 


\section{TABLE OF CONTENTS}

CHAPTER

PAGE

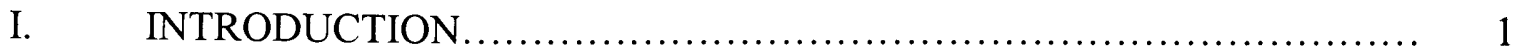

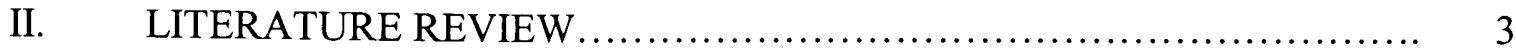

EXPLANATIONS FOR WRONGDOING .............................. 3

PERCEPTIONS OF ACCOUNTS ...................................... 6

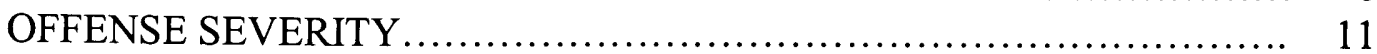

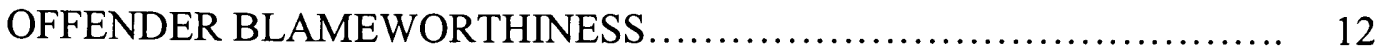

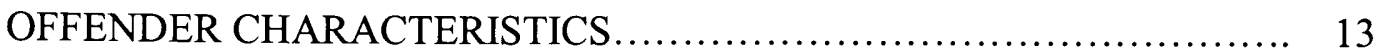

FACTORS AFFECTING DAMAGE AWARDS....................... 16

INJURY SEVERITY ............................................... 16

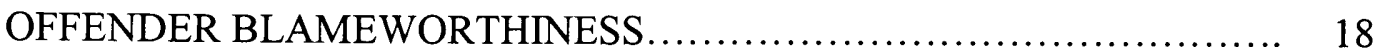

CORPORATE VERSUS INDIVIDUAL STATUS ...................... 21

OVERVIEW ...................................................... 27

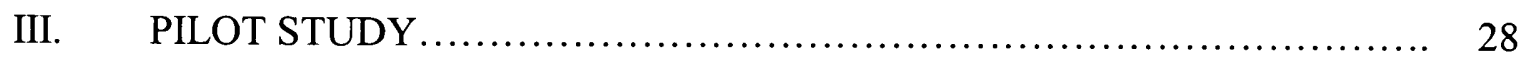

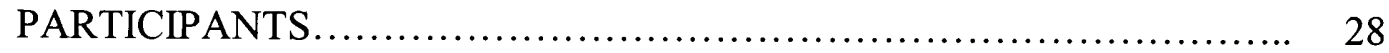

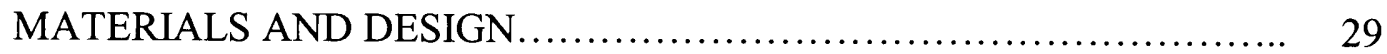

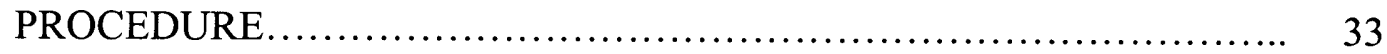

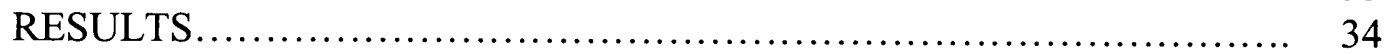

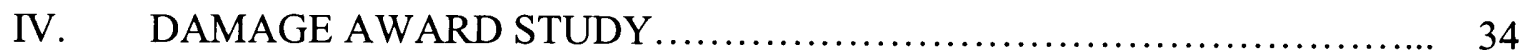

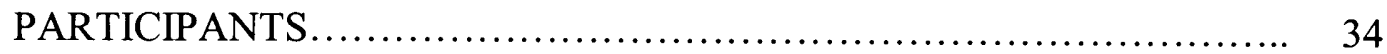

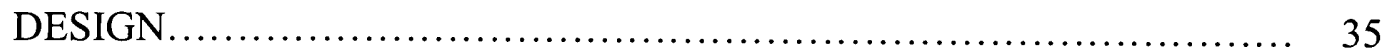

MATERIALS ....................................................... 36

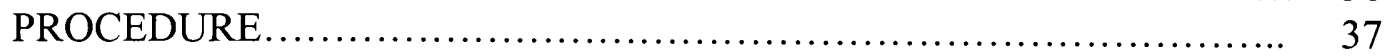

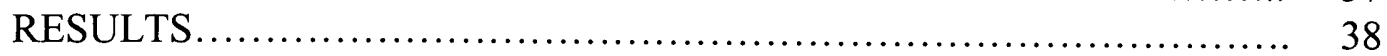

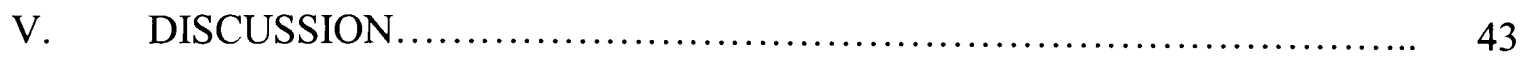

INJURY SEVERITY ............................................ 44

DEFENDANT REPREHENSIBILITY ............................... 46

CORPORATE STATUS ........................................... 49

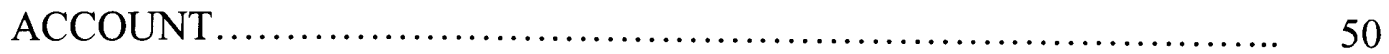

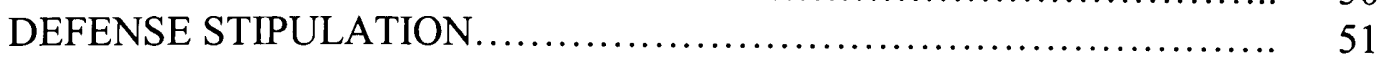

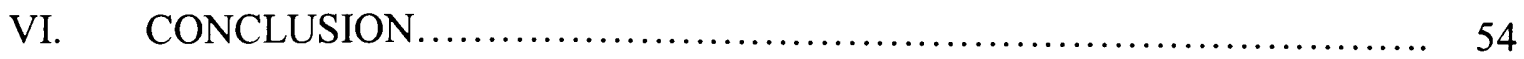

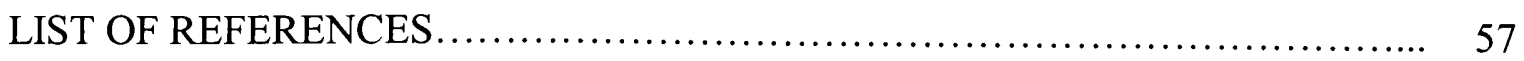

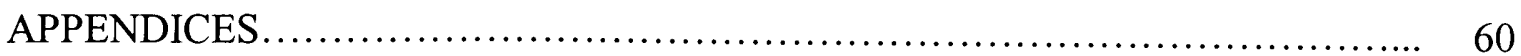

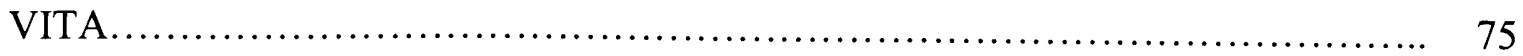




\section{LIST OF TABLES}

TABLE

PAGE

1. Mean Economic Damage Awards as a Function of Status, Reprehensibility, and Account.

2 Mean Pain and Suffering Damage Awards as a Function of Status and Account.

3. Mean Pain and Suffering Damage Awards as a Function of Status, Reprehensibility, and Account

4. Mean Economic Damage Awards as a Function of Status, Account, and Negligence Stipulation

5. Mean Pain and Suffering Damage Awards as a Function of Status and Account.

6. Mean Pain and Suffering Damage Awards as a Function of Status and 73 Account

7. Mean Pain and Suffering Damage Awards as a Function of Account and Negligence Stipulation 
In 1995, a civil suit was brought against Dow Chemical Corporation asserting that the breast implants manufactured by the company caused disease (Dow Chemical v. Mahlum, 1998). Dow Chemical was accused of selling a dangerous product, having knowledge of the product's danger, and misrepresenting that danger to the public. The corporation accepted full responsibility for the product they manufactured and apologized for the suffering of persons who received their product, but denied that their product caused disease. Dow Chemical's director of public issues management responded, "We are concerned about anybody who is suffering from ill health, no matter what the cause. Aside from that compassion...allegations that Dow Chemical in any way acted improperly, or in any way harmed Mrs. Mahlum, are simply not true" ("Breast Implant Lawsuit”, 1995). The Dow Chemical Corporation lost the case and was instructed to pay $\$ 3.9$ million in compensatory damages and $\$ 10$ million in punitive damages. Many similar cases followed and resulted in similar responses.

The Philip Morris Company and Firestone Tires have faced accusations about the harmfulness and addictiveness of cigarettes and a design defect in specific tire types, respectively (Insolia v. Phillip Morris, Inc., 1998; Rodriguez v. Bridgestone/Firestone, Inc., 2001). Both lawsuits accused the companies of being aware that their products were dangerous and failing to take corrective action or warn consumers of that danger. In addition, the companies were charged with misleading the public as to the safety of their products. Although these two cases are quite different, the companies responded in very similar manners. Both companies apologized for harm suffered, but adamantly denied full responsibility for the charges against them. Phillip Morris and Firestone have 
released statements denying any wrongdoing and claiming that at no time did they endanger the health or safety of the public by withholding information from consumers. Phillip Morris stated that "they made cigarettes as safe as the market would bear" and "deny they fixed nicotine levels to maximize addictiveness". They also argue "their customers understood and accepted the risks of smoking."(“Jury Picked”, 1998). Firestone claimed, "We take responsibility for our tires and our tires were part of the issue", but a tread separation should be merely an inconvenience, not a catastrophe. "We must look at the vehicle," rather than focus solely on the tire (Rodriguez v. Bridgestone/Firestone, Inc., 2001). Both companies' responses indicate that the blame for the incidents in question actually lies elsewhere.

These three cases are examples of civil lawsuits that attracted massive media attention. In each case a company was accused of wrongdoing that adversely affected other people. Once such accusations are made, the companies are forced to respond to the accusations. The companies may choose to accept responsibility and offer some type of explanation for their behavior or they may choose to deny any wrongdoing. Each of these three companies, accepted responsibility for their product, apologized for the harm suffered, but argued that their product was not bad. Dow Chemical Company denied that they had done anything wrong. Phillip Morris and Bridgestone/Firestone attempted to redefine the situation to place the blame somewhere other than on their company. Considering that several companies choose this defense approach in high profile cases, several interesting questions arise. How are such denials and justifications in these cases perceived? Are these denials or justifications beneficial to the companies? Would the companies be better served by admitting the wrongdoing and offering the public an 
apology? Would the public be more accepting of such mistakes if the companies accepted responsibility for their actions?

The purpose of civil lawsuits is to hold persons accountable for behavior that negatively influences the lives of others. One individual or company sues another individual or company for some harm, loss, or damage suffered. The plaintiffs, or injured parties, initiate a lawsuit based on the idea that another party is responsible for their suffering. The defendants are accused of either directly causing the injury to the plaintiffs or negligently failing to prevent the injury. In such cases, the plaintiff requests monetary damages from the defendant as compensation for the loss or harm suffered.

In response to plaintiff's claims, defendants are essentially asked to explain their behavior. Did they act in the manner stated by the plaintiff? If so, why? Should they have been expected to foresee the harm done? Much research has been done to examine how persons explain negative or hurtful behavior. Multiple studies have shown how different explanations are perceived and what types of explanations are most believable and effective. However, this research has dealt primarily with interpersonal relationships. Given that the primary task of civil defendants is to explain their behavior in a way that will portray them in the most favorable light, it is logical to assume that such research could benefit participants in civil litigation. This study focused on how differing defense explanations may influence decision-making in legal contexts.

\section{EXPLANATIONS FOR WRONGDOING}

Whether in a work, school, or social setting, most persons are required to account for their behavior on a regular basis. Given the frequency with which each person's behavior influences others, it is inevitable that some behaviors will not meet expectations 
or will cause another person to experience inconvenience, discomfort, or harm. There is a natural tendency to try to explain such shortcomings in an attempt to preserve or maintain a positive reputation in the eyes of another (Gonzales, Manning, \& Haugen, 1992).

There are several responses that one may give to an allegation of wrongdoing. Responses in such situations are known in the psychological literature as accounts. Schoenbach's (1980) account taxonomy defines four common types of accounts: concessions, excuses, justifications and refusals. In concessions, the wrongdoer admits the act occurred, accepts responsibility, and offers an apology. An excuse consists of not only an acceptance that one played a part in causing the act but also a reason why he/she should not be held fully responsible for the act. Justifications are offered when accused persons admit their involvement in the incident but attempt to explain the situation in a manner that portrays them in a more positive light. In essence, the accused tries to redefine the situation to look less blameworthy. A refusal is an outright denial of the situation or denial of any wrongdoing in the situation.

For example, after arriving late for an appointment, a colleague may explain his behavior in one of four ways. He may simply apologize for being late, admit that he was at fault, and offer to reschedule the appointment (concession). He may, instead, apologize for being late, but blame his tardiness on circumstances outside of his control, such as traffic (excuse). His third option is to attempt to make his tardiness not seem so bad. For example, he may say that he is sorry if his colleague had been waiting long, but then continue by commenting that he did not think the appointment time was set in stone (justification). Finally, he may simply deny being late (refusal). 
Use of the four account types can be seen in legal settings as well. Using a civil dispute concerning a car accident as an example, it is possible to see how each type of account could be considered when choosing a defense. Given a case in which the plaintiff sues the defendant for running a red light and causing an accident, the defendant may choose to explain the negligent behavior in several ways. A concession in this circumstance would consist of the defendant admitting to running the red light and causing the accident, and offering the plaintiff an apology. Another choice would be for the defendant to admit to partial causation for the accident and to offer an apology, but to blame the accident on weather conditions, faulty brakes, or some other circumstance beyond his control (excuse). The defendant, as a third option, could argue that although he is sorry for the plaintiff's injuries, but that the light was still yellow when he entered the intersection. Such a redefining of the situation constitutes a justification. Probably the most common explanation in this context is the refusal. A refusal would consist of the defendant arguing that the light was green, the accident was not his/her fault, and he/she did nothing wrong. Justifications and refusals are the strategies used by the three companies discussed previously.

As illustrated by this example, a civil defendant has several options when deciding how to explain the behavior in question. Realizing that there are several accounts available for use, the defense then must decide which account is most beneficial to their case. In cases in which liability is not clear, justifications and refusals may indeed lead to the lowest damage award decisions. However, in situations in which there is high evidence and liability is clear, would damages then be lower if the defense accepted responsibility and offered their apologies? Do certain accounts cause the jury to 
perceive the defense more favorably? If so, which accounts are most beneficial? Does the preferred type of account change depending on the specific facts of the case, such as injury severity or defendant reprehensibility? Does stipulating negligence or admitting liability reduce damage award amounts? What factors are usually considered when making decisions concerning the type of account to use or whether to stipulate negligence? What factors should be considered when making such decisions?

In a civil dispute, the deciding factor as to which account a defendant chooses to use is most likely how jurors will view each possible account. The goal of each side is to choose the account that jurors are more likely to relate to and believe. Jurors' perceptions of the defendant's account are instrumental to any decisions made in the case. These perceptions may determine which party will be believed, how liability will be determined, whether damages should be awarded, and if so, the amount of damages to award. The focus of the present investigation is to examine the influence of accounts on jurors' damage awards.

\section{$\underline{\text { Perceptions of Accounts }}$}

Researchers have investigated how people perceive different accounts by manipulating the type of account that is given following an offensive act and measuring participant reactions to that account. In one study, participants read scenarios of a politician engaging in unbecoming behavior, either on-the-job or during his private time (Riordan, Marlin, \& Kellogg, 1983). The scenarios included either an excuse or a justification to explain the behavior. The politician was held more responsible and the act was seen as more wrong when the offensive behavior was conducted on-the-job than when it was conducted during his private time. Explaining his behavior through 
justifications as opposed to excuses also led the participants to view the politician as more likely to engage in similar acts in the future. However, when the politician offered a justification for his behavior as opposed to an excuse, the perceived wrongfulness of the act was diminished. Therefore, excuses proved more beneficial in reducing the politician's responsibility for his behavior and in preserving his character. On the other hand, justifications were more effective in making the act seem less wrong.

Riordan, Marlin, and Gidwani (1988) propose that if the accounts are believed, then different types of accounts should lead to different results. The purpose of excuses has been defined as the attempt to convince others that one's negative actions are due less to inherent personal characteristics and more to situational or environmental characteristics (Snyder \& Higgins, 1988). According to the fundamental attribution error, observers tend to blame an actor's undesirable behavior on internal characteristics of the actor, rather than characteristics of the situation. Excuse-giving, therefore, is an attempt to convince the observer that the behavior was more dependent on the situation than would be otherwise assumed. If the excuse is effective in accomplishing this goal, then the actor's character or image should increase when the excuse is given.

Excuses, which deny any intent for wrongdoing, should result in a reduction in perceived need for punishment. This should be the case because accidents or unintentional acts are not generally punished. Justifications, on the other hand, attempt to redefine the situation so that it appears less negative. If a justification is believed, the result should be a more positive view of the situation, rather than a lessened need for punishment. Therefore, excuses should result in a less negative perception of the actor and justifications should result in a less negative view of the situation. 
Findings from a role-playing study did not support these hypotheses (Riordan, et al., 1988). In this study, psychologists read scenarios concerning unethical research practices. The researcher in the scenario was guilty of either plagiarism or data fabrication. After reading the researcher's account for his actions, the psychologists gave their opinions of the researcher, the researcher's work and actions, and the type of consequences they felt were appropriate. In contrast to what was expected by the researchers, the lowest level of perceived wrongfulness of the act was found when researchers accounted for the act with a denial. Excuses followed denials with justifications producing the highest level of perceived wrongfulness. The same trend was demonstrated when examining the researcher's decency, respectability, and goodness. For each of these three factors, researchers who offered denials were viewed more positively than those who offered justifications or excuses. In addition, researchers offering excuses were seen as less likely to commit such an act again and less likely to have their work discredited. Unexpectedly, the type of account given did not influence the psychologist's opinion of the proper consequences for the act.

Justifications have also been found to be the least helpful account type for the offender in research using traffic court scenarios. Participants read descriptions of incidents and accounts given in response to those incidents. They then rated the offender's moral responsibility, the offender's degree of blame, the influence of the offender's personality, and the offender's intent to break the law. Offender's intent to break the law and the influence of personal characteristics of the offender were seen as highest in situations in which offenders accounted for their behavior using justifications. In other words, offenders were held to the highest degree of personal responsibility for 
the occurrence when they attempted to justify their behavior (McLaughlin, Cody, \& French, 1990).

Contrary to other research, justifications received high ratings in a study designed to examine what factors influenced perceived outcome fairness in negotiation situations (Conlon \& Ross, 1997). The authors developed a negotiation scenario with different outcome possibilities in which a third party intervened and imposed a specific outcome. One of the manipulated factors was the type of account given by the third party for the imposed outcome. Concessions, justifications, and excuses were compared. Somewhat surprisingly, participant perceptions were found to be most positive when justifications were given. The imposed outcome was seen as fairer and more satisfactory when the third party explained his actions using a justification, rather than a concession or an excuse.

To be effective, an account must be plausible, consistent, and believable. In the same manner that certain accounts are perceived as more appropriate and acceptable, some accounts are also more effective in achieving specific goals. By manipulating the type of account offered across scenarios, researchers have examined which account types tend to be more effective (Benoit \& Drew, 1997). Across five scenarios, participants rated how appropriate the account response seemed and how effective they felt the account would be. Although the authors developed their own account typology, their results were consistent with previous findings. The highest effectiveness ratings were given in conditions in which offenders apologized and conditions in which the offender offered to take corrective action. Denials produced the lowest effectiveness ratings. 
When accounting for behavior, the goal is often forgiveness or excuse of the behavior. One researcher examined the type of account most conducive to that goal by having participants report to the laboratory and complete a questionnaire packet (Gonzales, 1992). Once the packet was completed, a researcher led the participants to believe that they had been given the wrong packet and that their responses were useless. The researchers then accounted for their actions using a concession, an excuse, or a refusal. Participants were then questioned by another researcher and asked to rate their research experience and the initial researcher. Ratings for the account-givers were more positive when the mistake was explained using a concession or excuse, rather than a refusal. In addition, participants in the concession or excuse conditions reported a greater likelihood that they would return in the future to redo the experiment than did participants in the refusal conditions.

In one of the few studies concerning accounts within the legal system, account effectiveness was determined by length of prison sentences. Felson \& Ribner (1981) examined the accounts proffered by New York State inmates convicted of murder, manslaughter, or felony assault and the sentences the inmates received. In cases of murder and first degree assault, the longest sentences were given in situations in which the offender denied his actions. This study indicates that the admission of wrongful acts resulted in greater leniency. However, there are many outside factors that suggest that these results must be interpreted with caution. First, the authors used written accounts by the inmates that were provided after, rather than before, the sentencing. It is possible to imagine that a percentage of the inmates may have altered their accounts following their sentencing. Furthermore, there are many aspects of violent crimes other than account type 
that may affect sentencing. Factors such as past record, degree of violence, and intentionality of the act may all exert a much greater influence on sentencing than the type of account given by the inmate. Experimental studies that controlled for such additional factors are needed in order to determine whether higher sanctions are actually imposed against defendants who offer denials rather than admissions of their guilt.

Another naturalistic study conducted within the legal system investigated the types of accounts offered in actual traffic court cases and the resulting fines levied against the offenders (Cody \& McLaughlin, 1988). Observers recorded the particulars of each case, the account offered by the offender, and the judge's punishment decision. Punishments were categorized as no fine, partial fine, or full fine. Denials accompanied by proof of innocence resulted in the greatest number of 'no fine' penalties. Partial fines, or fine reductions, tended to occur in cases in which offenders offered a concrete, rather than vague explanation for their behavior. Denials with no proof were less effective, and full fines were most likely when the offender offered concessionary accounts. Judges did not reduce fines because offenders accepted responsibility and offered apologies.

\section{Offense Severity}

Different accounts indeed do lead to different perceptions. Does the severity of the offense influence the manner in which the accounts are perceived? An examination of offense severity and account type found that participants were more likely to believe accounts in situations in which the behavior was less severe (Blumstein, Carssow, Hall, Hawkins, Hoffman, Ishem, Maurer, Spens, Taylor, and Zimmerman, 1974). Another study examined account-giving strategies within intimate relationships by incorporating not only the type of account offered by the offender, but the severity of the offense 
(Hupka, Jung, \& Silverthorn, 1987). In low severity conditions, the offending partner flirted with someone outside of the relationship. In high severity conditions, the offending partner had sexual intercourse with someone outside the relationship. Apologies and excuses were perceived as more effective when the severity was low rather than high. Offended parties rated justifications similarly regardless of severity condition.

The authors also manipulated whether the offender intended to maintain or end the relationship. If the offender's goal was to maintain the relationship, apologies and excuses were expected to be the most beneficial accounts. The authors based this prediction on the fact that both apologies and excuses take the offended party's face needs into consideration, which is important if the relationship is to continue.

Justifications, on the other hand, are an attempt to bolster the offender's self-image at the expense of the offended party. For this reason, justifications were expected to be more beneficial accounts in situations in which the offender wished to end rather than maintain the relationship. Data revealed that apologies were perceived as the best accounts. This held true both when offenders intended to maintain and when they intended to end the relationship. As predicted, justifications received the lowest ratings of the account types when the offender wanted to maintain the relationship. However, when offenders desired to end the relationship, justifications fared better than excuses.

\section{Offender Blameworthiness}

One factor that may influence how accounts are perceived is the degree of offender blameworthiness. Researchers manipulated both blameworthiness and account type within a single study (Gonzales, Haugen, \& Manning, 1994). Participants read 
scenarios and assumed the role of the offended party within each scenario.

Blameworthiness was manipulated by describing the offensive act as accidental, negligent, or intentional. Participant's reactions to the accounts did not differ in content. Estimated consequences and ratings of the given explanations were similar across account conditions. However, there were significant differences in the tones used in responding. More negative and sarcastic responses were given in the more blameworthy conditions. When the acts were intentional, account type did not alter participants' perceptions of the event. For accidental and negligent acts, account perceptions differed by gender. In accidental conditions, men tended to prefer concessions and excuses rather than justifications and refusals. Women demonstrated no account preference. The opposite gender trend was true for negligent offenses. Women tended to prefer concessions over other accounts and men did not demonstrate an account preference. $\underline{\text { Offender characteristics }}$

Offender characteristics and the delivery of the account also influence whether an account is honored or accepted once it has been given. Participants read a scenario involving the commission of an offense and how the offender accounted for the offense (Blumstein et al., 1974). The participants then evaluated the individuals in the scenario, the action, and the account. They then predicted how likely it was that the account would be accepted. The authors manipulated both the account type and the status of the individuals in the scenario. The status manipulation consisted of three conditions: the offending party of higher status than the offended party, both parties of equal status, and the offended party of higher status than the offending party. When the offender was of a 
higher status than the person offended, participants judged that accounts proffered were more likely to be believed than those offered by persons of an equal or lesser status.

Another factor that influenced the predicted acceptance of the given account was the offender's moral worth. Participants predicted that the accounts of offenders who they viewed as trustworthy, sincere, valuable, and responsible were likely to be believed. The likelihood that the act would be repeated and the degree of repentance also influenced the predicted acceptance of the account. Offenders that were deemed most likely to be believed were the offenders that appeared properly repentant and less likely to commit the same act again. Although these authors did not categorize the accounts based on Schoenbach's taxonomy, the accounts that were accepted were consistent with concessions and excuses.

The aforementioned research demonstrates that many factors influence how explanations for wrongdoing are perceived, and whether the explanation furthers the accounter's achievement of a particular goal. In the context of a civil dispute, this research highlights many interesting questions that have yet to be examined. The manner in which defendants account for their behavior could potentially influence the trial outcome in different ways. Jurors in civil cases must make several decisions. Initially, jurors must decide if the defendant was negligent and did indeed cause the harm or loss suffered by the plaintiff. If the defendant is found liable, then the jury must decide what amount of money, or damages, should be awarded to the plaintiff in order to make up for what he/she has suffered.

The current legal system allows damages to be awarded in two forms. The two forms of damages differ as to the purpose they are intended to serve. The first type of 
damages, compensatory damages, is meant to compensate the plaintiff for any suffered losses. The purpose of this type of award is to reinstate the plaintiff to the position in which he/she was prior to the incident in question. These damages are specified to cover losses such as medical expenses, loss of wages or support, and pain and suffering. The second type of damages, punitive damages, is meant to punish the defendant or teach the defendant a lesson for his/her poor conduct. This type of damages is intended to serve as punishment for wantonly negligent or reckless behavior and to deter such conduct in the future. Punitive damages are also meant to demonstrate to other persons or companies that such negligent behavior will not be tolerated.

Oftentimes in civil disputes, the argument does not lie in whether there was negligence on the part of the defendant. The question of liability is often quite clear. In fact, in many instances the facts of the case strongly demonstrate that the defendant was indeed negligent. The real argument between the parties concerns the amount of damages deserved by the plaintiff as a result of the defendant's negligence. As would be expected, the plaintiff generally asks for an amount that is much higher than the defendant deems fair or appropriate. In such cases, a question arises. Would it be beneficial to the defendant to stipulate negligence? Would an admission of fault win points with the jury and result in smaller damage awards? Jurors may be more sympathetic toward defendants who accepted responsibility and apologized for their actions. These kinder feelings toward the defendant might result in lower damage awards.

In particular, punitive damage awards, in which the purpose of the damages is to punish the defendant for his negligent behavior, may be especially sensitive to such a 
change. Jurors may be less likely to feel the need to punish an already apologetic defendant as opposed to a defendant who continually denies any wrongdoing. This study examines how defendant's accounts may affect both compensatory and punitive damage awards, specifically in situations where liability is clear.

\section{FACTORS AFFECTING DAMAGE AWARDS}

Various factors have been shown to affect civil damage awards. Given the distinct purposes of the two types of damage awards, different factors should be considered when deciding compensatory awards than when deciding punitive awards. Compensatory awards are meant to return to plaintiff to his or her prior state and as such, should be based solely on damages suffered by the plaintiff. Punitive awards, designed to punish and deter, should be based on characteristics of the defendant. The defendant's conduct and assets may be considered in order to determine an amount suitable to fulfill the punitive damage goals. However, in practice, it is apparently difficult for jurors to compartmentalize the types of damages in such a manner. Defendant's conduct and assets have been shown to affect not only punitive damage awards, but also compensatory damage awards (Cather, Greene, \& Durham, 1996; Carpenter, Kovera, \& Moran, 2000). The majority of research concerning factors that influence damage award decisions has focused on three factors: the severity of the plaintiff's injury; the degree of the defendant's blameworthiness, and the defendant's status as an individual or corporation.

\section{Injury Severity}

The degree of a plaintiff's injury often influences the amount of award presented to the plaintiff (Bovbjerg, Sloan, Dor, \& Hsieh, 1991; Cather et al., 1996). When 
considering compensatory damages, these findings are not only logical but in accordance with the law. Compensatory damages were designed to compensate plaintiffs for their injuries, and as such, should increase as the severity of the injury increases. Research has shown that this indeed occurs. An examination of damage awards in malpractice cases demonstrated that compensatory damages are positively correlated with injury severity (Bovbjerb, et al, 1991). The highest compensatory damages were awarded to the plaintiffs with the most severe injuries. Likewise, the lowest compensatory damages were awarded to the plaintiffs with the least severe injuries.

Compensatory damages are generally divided into several categories, including medical expenses, lost wages, and pain and suffering. One type of compensatory damage, pain and suffering, tends to be especially sensitive to variations in injury severity. Jurors are provided with explicit information as to medical expenses, previous salary of the plaintiff, and the amount of time that the plaintiff will be unable to work. Based on the information they are given, jurors can make directed decisions about how to compensate the plaintiffs for their medical bills and lost wages. When deciding pain and suffering awards, however, jurors are not provided with such direction. Placing a monetary value on the abstract notion of pain and suffering may be understandably difficult for jurors. In addition, this category offers jurors more leeway in their decisionmaking and as a result is more open to the influence of outside factors. Pain and suffering awards are strongly influenced by the severity of injury to the plaintiff. As one would logically predict, jurors awarded higher pain and suffering awards to plaintiffs who endured the most severe injuries (Wissler, Evens, Hart, Morry, \& Saks, 1997). These findings are both understandable and legally sound. 
Findings from research examining whether injury severity improperly influences punitive award decisions have been mixed. Relationships have been demonstrated between injury severity and punitive awards. In one study, severely injured plaintiffs received higher punitive awards than mildly injured plaintiffs; punitive damages tended to be awarded only in cases in which the plaintiff suffered a severe injury (Koenig \& Rustad, 1993). In another study, researchers found only marginally significant effects for injury severity on compensatory awards, and no significant effects for injury severity on punitive awards (Cather, et al., 1996).

The influence of injury severity on damage awards is well established. This study will examine the interplay between account type and injury severity and address several unanswered questions. Will the influence of injury severity on damage awards be moderated by account type? Will differences in accounts only demonstrate effects on awards when injury severity is low? The literature on accounts indicates that accounts are most effective in situations where the offense is less severe (Blumstein et al., 1974; Hupka et al., 1987). For this reason, differing accounts may demonstrate greater effectiveness when the injury severity is low and lesser effectiveness when the injury severity is high.

\section{Defendant Blameworthiness}

Another factor that jurors consider when making damage award decisions is the wrongfulness of the defendant's conduct. Jurors award higher damages when the defendant's conduct is more reprehensible (Carpenter et al., 2000). According to the law, defendant reprehensibility should influence punitive damage awards. Because compensatory awards are designated to repay specific damages suffered by the plaintiff, 
defendant reprehensibility should not influence compensatory decisions. In contrast, because the purpose of punitive awards is to punish and deter, the wrongfulness of the defendant's conduct should influence punitive damages awarded.

In alignment with legal intentions, the extent of wrongdoing does influence punitive award amounts. One study asked mock jurors to make damage award decisions in a case concerning harmful chemicals being released into an area (Horowitz \& Bordens, 1990). The chemicals were released during a corporation's manufacturing process and several plaintiffs alleged physical ailments as a result of the chemicals. When the defendant had a greater length of time to foresee the problems, the jurors levied higher punitive awards against the defendants. Also, as perceived responsibility on the part of the plaintiff diminished, the punitive award amounts increased. Both of these findings indicate that higher punitive awards are given in situations in which the defendant is perceived as more blameworthy.

Further research indicates that defendant blameworthiness may affect compensatory awards as well as punitive awards. To determine whether jurors based their damage award decisions on the proper legal factors, researchers manipulated several factors including defendant reprehensibility (Cather et al., 1996). Reprehensibility of the defendant significantly influenced punitive awards. Higher punitive awards were given in cases involving highly reprehensible defendants. In addition, a trend indicated that jurors levied higher compensatory awards against more reprehensible defendants. Wissler et al.'s (1997) study of pain and suffering awards provides further support to the notion that defendant blameworthiness influences compensatory awards. Jurors were 
somewhat more likely to award higher compensatory damages in conditions of high defendant fault in comparison to conditions of low defendant fault.

In another study, defendant reprehensibility significantly influenced both compensatory and punitive damage awards (Carpenter et al., 2000). After reading a case scenario in which liability had already been determined, participants were instructed to determine appropriate damage awards. Holding other factors constant, higher damages were awarded in conditions in which the defendant's actions were highly reprehensible. These findings held true regardless of the type of damage award. Therefore, despite legal intentions, defendant reprehensibility has been shown to affect both compensatory and punitive damages. Defendants who are more culpable in the eyes of the jury are punished for their culpability through both higher compensatory and higher punitive damage award decisions.

Perceived defendant reprehensibility has been shown to raise or lower the amount of money awarded to the plaintiff. Based on these studies and the evidence provided therein, it is reasonable to hypothesize that altering the manner in which the jury perceives the defendant, may in turn alter the damage award decision. One way in which it may be possible to change how jurors view defendants is by changing the way defendants explain their negligent behavior. Will the account offered by the defendant strengthen or reduce these perceptions of culpability? Will the type of account exert a stronger influence when reprehensibility is low than when it is high? Past research demonstrates that accounts are perceived differently when given by less blameworthy offenders as opposed to more blameworthy offenders (Gonzales et al., 1994). When the offender was highly blameworthy, account type did not influence participants' 
perceptions. Based on that research, jurors may view highly reprehensible defendants more harshly regardless of the explanation given. However, when the defendant is less reprehensible, certain accounts (concessions and excuses) should prove more beneficial than others (justifications and refusals).

\section{Corporate Versus Individual Defendants}

The identity of the defendant is another factor that may influence damage award decisions. Damage awards differ when the defendant is a corporation rather than an individual, even when all other facts of the case are held constant (Hans \& Ermann, 1989; MacCoun, 1996). Several theories have emerged to explain why jurors hold corporations to a different standard than they hold individuals.

The "deep pockets" theory proposes that defendants who appear to have more money are required to pay higher damage awards than defendants who have less money. In other words, jurors may assign damage awards based on the defendant's ability to pay. Jurors may assume that corporations have more money than an individual, and as a result would be in a better position to pay higher damage awards. Chin and Peterson (1985) examined verdict data collected from Cook County, Illinois and as predicted, higher damages were awarded against corporate defendants than against individual defendants. These findings were the result of an analysis of archival data, rather than an experimental study and when comparing actual cases it is impossible to hold constant all factors other than the defendant's status. For example, cases against corporations are more likely to have multiple defendants and are more likely to be high stakes cases than cases against individual defendants. Thus, it is impossible to draw conclusions about causation. However, when a statistical analysis was done to control for other factors, such as 
number of defendants, the differences between corporate and individual awards still emerged. These differences were greatest in situations in which the plaintiff's injuries were severe.

In one mock jury experiment, participants were assigned to groups and told that they were going to make damage award decisions concerning a civil trial (Wasserman \& Robinson, 1980). In the individual conditions, the defendant was an individual by the name of Mr. Holden who earned around $\$ 30,000$ per year and did not have any insurance. In the corporate conditions, the defendant was identified as Holden Corporation, an "average" corporation with approximately $\$ 2$ million in assets. Aside from the identity of the defendant, all other case characteristics remained the same. All mock jurors were told that the defendant had admitted full responsibility for the accident and that their responsibility was to determine an appropriate damage award amount. Participants in this study made a single damage award decision, with no distinction between compensatory and punitive awards. Jurors awarded significantly more money to the plaintiff when the defendant was a corporation as opposed to an individual providing evidence in support of the deep pockets hypothesis.

Upon further examination of the research conditions used in this study, alternate hypotheses emerge. One important difference between the two groups is the description of the defendant's income. By giving information as to the income of the defendants, the experimenters introduced an additional factor into the study. The participants are explicitly told that assets of the corporation tremendously outweigh the income of the individual. This difference alone could produce differences in damage awards. In addition, insurance information is included in the individual condition, but is not included 
in the corporate condition. It is possible to imagine that mock jurors could have based their decisions on the likelihood that a corporation would have insurance to cover such damages, whereas the individual did not. In conclusion, although a corporate/individual difference was found in damage awards, this difference may be attributable to factors other than the status of the defendant.

Several other studies have examined jurors' responses to wrongdoing on the part of individuals as compared to corporations. In one experiment, participants read information about a civil case in which persons became ill after being subjected to harmful materials by either Mr. Jones or Jones Corporation (Hans \& Ermann, 1989). No further descriptions of the defendants were given, and the only difference between the case scenarios was the name of the defendant. Participants were asked to make liability and compensatory damage award decisions in this case. The compensatory award decisions were broken down into four categories: hospital bills, doctor bills, pain and suffering, and total award. Consistent with past findings, corporate defendants were required to pay higher damages than individual defendants. These findings held true across all four categories of damages. Moreover, the corporate defendant was significantly more likely to be found liable than the individual defendant.

New reasons for these findings emerged. In the past, damage award discrepancies between corporate and individual defendants had been attributed to the deep pockets theory. Hans and Ermann (1989) theorized that such a discrepancy could be due to corporations being held to a higher standard of conduct than individuals. Thus, when mistakes are made or people are injured, the public is more outraged by corporate wrongdoing than individual wrongdoing. Indeed, the authors did find that the corporate 
conduct, although identical to the individual conduct, was viewed as more reckless and the resulting injuries as more foreseeable.

MacCoun (1996) tested the "deep pockets" theory versus the "higher standard" theory more directly. Past experiments testing the deep pockets hypothesis contained a confound. The deep pockets hypothesis is based on the wealth of the defendant.

Defendants that are perceived as more wealthy would be required to pay higher monetary damages than less wealthy defendants. Past research has tested this by comparing damages levied against corporate defendants with damages levied against individual defendants. When findings indicated that corporate defendants were required to pay larger awards than individuals, experimenters cited such results as support for the deep pocket hypothesis. MacCoun (1996) noted that such experiments confound wealth with defendant's status as a corporation or individual. To eliminate this confound, the author designed an experiment with three defendant conditions: a wealthy corporation, a wealthy individual, and a poor individual. The defendant's assets were described identically in the wealthy individual condition and the wealthy corporation condition. In this way, it could be determined whether the disparity in damages was the result of defendant wealth, as the deep pocket hypothesis states, or the result of corporations being held to a different standard than individuals.

Participants read several scenarios and decided liability and damages in each case. As was found previously (Hans \& Ermann, 1989), participants were more likely to find corporate defendants liable than they were to find individual defendants liable. There was no difference in liability decisions between the two types of individual defendants, however. The same trend held true for damage decisions as for liability decisions. There 
were no significant differences between damage awards for the wealthy and the poor individual; however, awards against corporate defendants were significantly higher than awards against wealthy individual defendants.

According to the deep pocket hypothesis, defendants of comparable wealth should be treated similarly and should be required to pay larger damage awards than defendants of lesser wealth. MacCoun (1996) demonstrated that when defendant wealth was held constant, the corporate/individual bias remained. These results are inconsistent with the deep pocket theory. Such findings tend to lend support to the theory that corporations are held to a higher standard of conduct than individuals (Hans \& Ermann, 1989). In addition, they raise questions as to the accuracy of the widely held beliefs concerning deep pocket defendants.

Further research provides additional support for the notion that corporations are required to pay higher damages than individuals. After reading a case scenario and judicial instructions, community members who had reported for jury duty decided both compensatory and punitive damages (Carpenter, et al., 2000). The judicial instructions contained the information that the defendant had previously been found liable for damages suffered by the plaintiff. The sole responsibility of the participants was to decide what amount of damages was fair and reasonable. Holding all other case factors constant, the identification of the defendant as a corporation or an individual influenced both type of damage awards. In punitive award decisions, in which assets of the defendant may be considered, significantly higher damages were awarded against corporate defendants than individual defendants. In compensatory award decisions, in which decisions should be based solely of plaintiff characteristics, there were marginally 
significant differences with awards against corporations again higher than those against individuals.

Regardless of the reasoning, corporate defendants can expect to be held to a different standard than individual defendants. As a result of this different standard, an abundance of research indicates that higher damage awards tend to be levied against corporate defendants. This appears to hold true for both compensatory and punitive damage awards. This evidence leads to questions concerning corporate versus individual accounts. Will accounts proffered by corporations be perceived differently than accounts proffered by individuals? Will an apology by an individual be more easily accepted than an apology from a corporation? Will different accounts be more effective for corporations than for individuals? Research demonstrates that corporations are held to a higher standard than individuals (Hans \& Ermann, 1989). Participants regard mistakes by corporations as more offensive than mistakes by individuals. The account literature shows that accounts are less effective for more offensive behavior than for less offensive behavior. Therefore, mock jurors may be more receptive to accounts given by individuals than to those given by corporations.

This literature demonstrates that a variety of factors, either in congruence with or in opposition to what was legally intended, influence the way that jurors make damage award decisions. Case-specific factors, such as injury severity, defendant reprehensibility, and defendant status influence damage award amounts. Research has also shown that the type of account that is given to explain an act influences the way that the act and actor are perceived. Given that evidence, the account that defendants offer for their actions may influence how jurors perceive them. In turn, juror perceptions 
influence damage awards. By examining the account literature in the context of civil disputes, it is possible to examine whether the way defendants choose to explain their behavior directly or indirectly influences the amount of damages awarded to plaintiffs. Common legal practice dictates that civil defendants should deny responsibility for the negligent act or attempt to place the responsibility elsewhere. However, through research such as this, it can be determined whether accepting responsibility in the liability phase of a civil trial would actually benefit the defendant in the damage phase of the trial. This question is particularly pertinent in cases in which there is high evidence of defense liability.

Overview

The purpose of this research was to examine whether the account given by the defense would affect either compensatory or punitive award decisions. This was done by examining the effects of four types of accounts that can be given to explain behavior within a legal context on juror decisions. I compared denials, the typical account used in civil disputes, to the other available accounts, to determine whether a more apologetic account would influence the damage phase of the trial. The value of a more apologetic strategy would be evident only in cases in which the liability is quite clear in favor of the plaintiff so that was the focus of this study. In addition, I manipulated severity of plaintiff injury, reprehensibility of the defendant, and the defendant's status as a corporation or an individual to ascertain whether these factors interacted with the type of account offered. Each of these factors was examined across three civil case scenarios to increase the generalizability of these findings. In each of these three cases, the defendant was clearly 
liable for the plaintiff's injuries. I also examined whether a defense stipulation of negligence, as opposed to no stipulation of negligence, would affect damage awards.

Based on the previously presented research, the following hypotheses were generated.

Hypothesis 1a. Account type will not affect compensatory awards.

Hypothesis $1 b$. Punitive awards will be smaller when defendants proffer concessions and excuses, than when they proffer justifications and refusals.

Hypothesis 2. Higher levels of injury severity and higher levels of defendant reprehensibility will result in higher compensatory and punitive damage awards.

Hypothesis 3. Jurors will assess higher compensatory and punitive damage awards against corporate defendants than against individual defendants.

Hypothesis 4. Account type will have a greater effect on punitive awards when the injury is low as opposed to when it is high.

Hypothesis 5. Account type will have a greater effect on punitive awards when defendant reprehensibility is low as opposed to when it is high.

Hypothesis 6. Concessions and excuses will not be as effective in lowering damage awards when offered by corporations as when offered by individuals.

Hypothesis 7. When an apologetic account (concession or excuse) is given, stipulations of negligence will lead to lower damage awards than will jury decisions of negligence.

Pilot Study

\section{$\underline{\text { Participants }}$}

Eighty-two jury-eligible community members served as participants for the pilot testing of this study. I recruited participants from the jury pools at the Dade and Broward 
County Courthouses. Potential jurors who had not been selected as the end of the day drew near were asked to volunteer to participate in this experiment. All participants were informed that their participation was voluntary and their responses were anonymous. Participants were not compensated for their participation.

\section{Materials and Design}

Each participant received a survey packet that contained several portions. The first page in the packet was an informed consent form. This form outlined that juror participation was voluntary and that their answers would not be connected to their names. In addition, this page provided general information about the purpose of the experiment, thanked the participants for their help, and provided information about how to contact the experimenter if they wished to receive results of the experiment.

The next section of the survey packet consisted of three civil case scenarios. Each scenario contained descriptions of the plaintiff and the defendant, a brief case summary, and an outline of the injuries suffered by the plaintiff. Following the case summary was a set of judge's instructions. The instructions stated that a jury had found the defendant liable and asked participants to decide both compensatory and punitive damage awards. The case scenarios include a product liability case, an auto negligence case, and a medical malpractice case (Appendix A). All cases were revisions of scenarios tested by Greene, Johns, and Smith (in press).

Product Liability Case. In this case, an employee (plaintiff) who demonstrated cleaning products became ill from the products, and as a result is suing her employer (defendant). The employer is accused of not providing sufficient warnings about the dangers of the product. The defendant is described as either a corporation (Morgan 
Chemicals, Inc.) or an individual (Robert Morgan) who did not follow federal standards in the labeling of their product.

The plaintiff developed asthma and respiratory problems as a result of inhaling the cleaning product while performing her work duties. In the low injury severity conditions, a doctor instructed the plaintiff to work only part-time and states that the plaintiff can expect flare-ups when she is tired or stressed. In the high injury severity condition, the doctor advised that the plaintiff may work only part-time for the time being and that within the next ten years her condition is likely to worsen leaving her unable to work. She is also likely to develop lung cancer and emphysema and must have respiratory therapy for the remainder of her life.

In low reprehensibility conditions, a chemist who worked for the company reviewed the label and did not recommend any changes. In the high reprehensibility condition, the label was inconsistent with the safety data sheet for the product. The safety sheet warned of the dangers of breathing vapors from the cleaner and stated that the cleaner contained caustic chemicals. The label claimed that the cleaner contained no caustic chemicals and contained no warning.

The defendant explains the questionable behavior in one of four ways. In one scenario, the defendant accepts responsibility, apologizes, and describes new techniques employed by the company to prevent such occurrences in the future (concession). As an excuse, the defendant explains that the chemist responsible for the safety labeling was going through a divorce and suffering from depression. He made a mistake when reading the safety sheet and mislabeled the product. The justification account states that internal testing demonstrated no dangers associated with the chemicals and therefore no warnings 
were needed. In the final scenario, the defendant denies any fault for the plaintiff's illness (refusal).

Medical Malpractice Case. This case concerns a stroke victim who received inadequate care in a nursing home facility. Following his stroke, a gentleman was placed in the nursing home. After a period of time, he had to be returned to the hospital and doctors found that he was malnourished and suffering from an infection due to bedsores. The plaintiff, the victim's wife, sued the nursing home for medical negligence on behalf of her husband. The defendant is described either as Peri-Care, Inc. (corporation) or Raymond Perry (individual).

In the mild injury condition, the victim was malnourished and had a 4-inch gangrenous bedsore. He required hospitalization for two weeks and it was a month before he returned to his prior state. In the severe injury condition, the victim was badly malnourished with a 10-inch gangrenous bedsore. An infection from the bedsore left him in intensive care for three weeks and he will never return to his prior state of health. Lower reprehensibility conditions state that nursing home records were not properly kept and were often falsified. In high reprehensibility conditions, there was also poor record keeping and record falsification. In addition, the facility was short-staffed and an exemployee testified to poor care of the nursing home residents and improper conduct of other employees, such as sleeping and smoking marijuana on the job.

The defendant gives one of the following accounts for their behavior. In the concessionary account, the defendant accepts responsibility for the occurrence, offers an apology and tells of changes that have been instituted since the incident. The excuse account offers an apology followed by the claim that the primary nurse was having 
personal difficulties and falsified the records. The justification states that the victim was already in poor health and his condition was caught before it got too serious. In the refusal, the defendant asserts that the facility is in no way responsible for the victim's injuries.

Automobile Negligence Case. This case concerns injuries resulting from an automobile accident. A truck driver was en route to a delivery when he entered a construction zone. Upon entering the construction zone, the truck driver lost control of his vehicle and the front axle from his truck struck another car injuring the plaintiff. The plaintiff is suing the defendant alleging that the driver was negligent. The defendant is defined either as Anderson Trucking Corporation or Robert Anderson (owner of the trucking company).

In the mild injury condition, the plaintiff suffered a concussion and some soft tissue injuries. He is fully mobile but will be forced to endure pain for the remainder of his life. In the severe injury condition, the plaintiff suffered skull fractures and was in a coma. He emerged from the coma but is still bedridden and mute. He will most likely remain completely dependent for the remainder of his life. In the low reprehensibility condition, the driver was driving approximately $5 \mathrm{mph}$ over the speed limit and had one speeding ticket in the last 6 years. In the high reprehensibility condition, the driver was driving approximately $15 \mathrm{mph}$ over the speed limit, did not use the proper braking technique, and had 3 speeding tickets in the last 6 years.

The defendant accounted for the behavior in four different manners. In one scenario, the defendant admitted wrongdoing and apologized (concession). Another scenario consists of an apology and a claim that the construction zone was not well 
marked and the accident was beyond the driver's control (excuse). The next scenario proposed that although the driver did cause the wreck, he handled the truck very effectively and prevented the accident from being much worse (justification). In the final account, the defendant accepts no responsibility for the accident (refusal).

\section{Procedure}

After reading each scenario, participants indicated their agreement to a series of statements, which served as manipulation checks, on 7-point Likert-type scales with higher numbers representing stronger agreement. To assess the effectiveness of the injury severity manipulations, I averaged participant's ratings of three statements across the three scenarios: the plaintiff's life will never be the same as a result of this incident, the degree of pain and suffering on the part of the plaintiff was minimal, and the plaintiff's injuries were not severe (Cronbach's alpha $=78$ ). To assess the effectiveness of reprehensibility manipulation, I averaged participant ratings of three additional statements across the three scenarios: the defendant's behavior was reckless, the defendant acted in this manner knowing that harm would occur, and the necessary precautions to prevent this type of incident were taken (Cronbach's alpha $=.74$ ). Corporate status was assessed by averaging responses to the statements: a damage award will cause financial hardship for the defendant and the defendant should have no difficulty paying an amount awarded against him (Cronbach's alpha $=.77)$. Averaged responses to the statements the defendant truly regrets his behavior, the defendant appears to regret his actions, and the defendant accepted responsibility for his actions assessed the account manipulations (Cronbach's alpha $=.87$ ). 


\section{$\underline{\text { Results }}$}

For each of the manipulation checks, I conducted a 4 (Account) X 2 (Injury Severity) X 2 (Reprehensibility) X 2 (Corporate Status) X 3 (Case Type) repeated measures analyses of variance (ANOVAs) with case type as a within-subject variable. The injury severity manipulation produced a significant main effect on jurors' perceptions of injury severity, $\underline{F}(1,50)=24.03, \underline{p}<.001, \eta^{2}=.33(\mathrm{Ms}=6.00$ and 7.44 for low and high injury severity, respectively). Ratings of defendant reprehensibility differed significantly as a function of the reprehensibility manipulation, $\underline{F}(1,50)=11.58$, $\mathrm{p}<.001, \eta^{2}=.19(\mathrm{Ms}=4.87$ and 5.94 for low and high reprehensibility, respectively). Manipulation of defendant status significantly affected juror perceptions of defendant wealth, $\underline{\mathrm{F}}(1,47)=7.84, \underline{\mathrm{p}}<.007, \eta^{2}=.14(\mathrm{Ms}=5.19$ and 6.14 for individual and corporate defendants, respectively). Additionally, account type affected juror perceptions of defendant's remorse, $\underline{\mathrm{F}}(3,50)=18.43, \underline{\mathrm{p}}<.001, \eta^{2}=.55(\mathrm{Ms}=5.99,4.02,3.24$, and 2.83 for concessions, excuses, justifications, and refusals, respectively). Because jurors appeared to perceive my manipulations as I intended, I proceeded to collect data on the types of damage awards jurors would make in response to these scenarios.

\section{Damage Award Study}

\section{$\underline{\text { Participants }}$}

Five hundred and forty-one jury-eligible community served as participants in this study. I recruited participants from the jury pools at the Dade and Broward County Courthouses. Potential jurors who had not been selected as the end of the day drew near were asked to volunteer to participate in this experiment. All participants were informed 
that their participation was voluntary and their responses were anonymous. Participants were not compensated for their participation.

\section{$\underline{\text { Design }}$}

The experiment was a 4 (Account: Concessions, Excuses, Justifications, vs. Refusals) X 2 (Injury Severity: High vs. Low) X 2 (Reprehensibility: High vs. Low) X 2 (Corporate Status: Individual vs. Corporate) X 3 (Case Type: Product Liability, Medical Malpractice vs. Automobile Negligence) factorial design with case type as a withinsubject variable. In each of these scenarios, participants were told that a jury had already found the defendant liable and that it was their duty to assess damages.

Four dangling control conditions were added in which the participants were told that the defense had stipulated negligence. This stipulation of negligence is in contrast to the remainder of the conditions, which stated that a jury had previously found the defendant liable. I predicted that account would have the greatest effect when injury was mild and reprehensibility was low. Therefore, in all four dangling control conditions, injury severity was mild and defendant reprehensibility was low. I used only two types of accounts in these conditions as justifications and refusals are not compatible with a defense stipulation of negligence. Therefore, in each of the four conditions, the account type is either a concession or an excuse. I also manipulated corporate status as I felt that a stipulation of negligence by a corporation might be perceived differently by jurors than a stipulation of negligence by an individual. The resulting four conditions included a concession/individual condition, a concession/corporate condition, an excuse/individual condition, and an excuse/corporate condition. In each group, injury severity was mild, reprehensibility was low, and the defendant stipulated negligence. 


\section{$\underline{\text { Materials }}$}

Each survey packet included the three case scenarios described in the pilot materials and one type of account for all three scenarios. In other words, within each packet, the type of account given to explain the facts was held constant. The scenarios were counterbalanced to prevent position effects. Reprehensibility level, injury severity, and corporate status were also held constant across the three scenarios within each packet. For example, if one scenario consisted of a defendant of higher reprehensibility, then both of the other two scenarios within that packet also consisted of defendants with higher reprehensibility.

Immediately after reading the case information, participants read judge's instructions and made damage awards decisions (Appendix B). For compensatory awards, participants read instructions informing them that compensatory awards were designed to return the injured party to his/her former state. The instructions then prompted participants to enter an amount that they felt would fairly and justly compensate the plaintiff for the harm suffered. Each scenario provided three categories for which compensatory damages could be awarded. These categories included medical expenses, either loss of wages or loss of consortium, and pain and suffering. After making compensatory decisions, judicial instructions informed participants that punitive awards were intended to punish the defendant for untoward conduct and to deter like conduct, by this defendant or other defendants in the future. Instructions then prompted jurors to provide an amount they felt would satisfy this purpose, if necessary. Following their award decisions on each case were questions about the participants' feelings and attitudes about each case (Appendix C). The questions in this section were those used in 
the pilot study to check on the effectiveness of the manipulations. These questions were answered immediately after the participants made award decisions on each case. As in the pilot study, the reliability of three of the scales created from these measures were adequate (alpha for injury severity $=.78$; defendant wealth alpha $=.68$; remorse alpha $=$

.87). Although the reprehensibility scale obtained adequate reliability in the pilot study $($ alpha $=.74)$, the reliability for the reprehensibility scale in this study was lower $($ Cronbach's alpha $=.59)$

There were three sets of these questions in each packet so that a set of questions followed each case scenario. The set of questions asked after each case was identical. In this way, participants read a case summary, made compensatory and punitive damage award decisions, and then answered a set of questions about that case. The participants then moved on to the following case summary, which was followed by questions to be answered concerning that case and so on. All questions about a specific case were answered before the participant moved on to the next case.

The final portion of the survey packet was a brief demographic questionnaire (Appendix D). This questionnaire asked general information about each participant and provided researchers with information about the demographic make-up of the sample.

\section{Procedure}

The experimenter announced to Dade and Broward County venirepersons that a study was being conducted to examine jury decision-making in civil cases. Venirepersons were informed that the study consisted of reading civil cases summaries and making damage award decisions based upon those summaries. They were told that after those decisions were made, they would be asked to complete the brief questionnaire 
that follows. The surveys were randomly distributed to volunteers who were asked to read an informed consent, read the case scenarios, and fully complete the questionnaire. Once the questionnaire was completed, the participants returned it to the experimenter. At that point participants were allowed to ask the experimenter any questions they may have had and then each was thanked and debriefed.

\section{Results}

Separate 4 (Account) X 2 (Injury Severity) X 2 (Reprehensibility) X 2 (Corporate Status) X 3 (Case Type) repeated measures analyses of variance (ANOVAs) with case type as a within-subject variable were performed for the economic, non-economic, and the punitive damages. The three levels of case type were included in this study to ensure that any results will generalize and that results were not case-specific. Results from these ANOVA's demonstrated few effects for case type. Out of 105 possible interactions between scenario and one of the manipulated variables, only sixteen proved significant. The small number of significant interactions, as compared to the large number of possible interactions, indicates that the significant results were most likely due to chance. As a result, I collapsed across case type and reanalyzed the data. I performed the following analyses on the collapsed data.

\section{Manipulation Checks}

For each of the manipulation checks, I conducted a 4 (Account) X 2 (Injury Severity) X 2 (Reprehensibility) X 2 (Corporate Status) X 3 (Case Type) repeated measures analyses of variance (ANOVAs) with case type as a within-subject variable. The injury severity manipulation produced a significant main effect on jurors' perceptions of injury severity, $\underline{\mathrm{F}}(1,410)=105.61, \underline{\mathrm{p}}<.001, \eta^{2}=.21(\underline{\mathrm{Ms}}=6.26$ and 7.46 
for low and high injury severity, respectively). Ratings of defendant reprehensibility differed significantly as a function of the reprehensibility manipulation, $\underline{F}(1,410)=$ 108.04, $\mathrm{p}<.001, \eta^{2}=.21(\underline{\mathrm{Ms}}=5.19$ and 6.32 for low and high reprehensibility, respectively). Manipulation of defendant status significantly affected juror perceptions of defendant wealth, $\underline{\mathrm{F}}(1,402)=35.79, \underline{\mathrm{p}}<.001, \eta^{2}=.08(\underline{\mathrm{Ms}}=5.10$ and 5.99 for individual and corporate defendants, respectively). Additionally, account type affected juror perceptions of defendant's remorse, $\underline{F}(3,409)=103.76, \underline{p}<.001, \eta^{2}=.43(\underline{\mathrm{Ms}}=$ $5.92,4.17,3.59$, and 2.82 for concessions, excuses, justifications, and refusals, respectively). Because jurors appeared to perceive my manipulations as I intended, I proceeded to analyze the data on the types of damage awards jurors would make in response to these scenarios.

\section{Compensatory Damages}

For purpose of analysis, compensatory awards were divided into economic and non-economic damages. Economic damages consist of all awards except pain and suffering and non-economic damages are made up solely of pain and suffering awards. All analyses were conducted on log-transformed data because the data were positively skewed. However, for clarity of explanation, reported means were derived from nontransformed data.

A 4 (Account) X 2 (Injury Severity) X 2 (Reprehensibility) X 2 (Corporate

Status) ANOVA was performed on the economic awards. For economic awards, the only significant main effect was for injury, $\underline{\mathrm{F}}(1,440)=51.38, \underline{\mathrm{p}}<.001, \eta^{2}=.11$. Jurors awarded higher economic damages to plaintiff's who were severely injured $(\underline{\mathrm{M}}=$ 
$135,656, \underline{\mathrm{SD}}=7022)$ than to plaintiffs whose injuries were less severe $(\underline{\mathrm{M}}=84,053, \underline{\mathrm{SD}}=$ 7045).

There was also a marginally significant 3-way interaction of Status $\mathrm{X}$ Reprehensibility X Account, $\underline{\mathrm{F}}(3,440)=2.60, \underline{\mathrm{p}}<.052, \eta^{2}=.02$ (see Table E1 for means). Simple effects analyses revealed that the interaction was driven by the interaction of defendant status and defendant reprehensibility when the defendant proffered a justification for the alleged wrong-doing. When a corporate defendant proffered a justification, defendant reprehensibility did not affect jurors' economic awards, $\underline{\mathrm{F}}(1,440)<1$, ns. In contrast, when an individual defendant proffered a justification, jurors' awarded higher economic damages when the defendant's actions were highly reprehensible than when the defendant's actions were low in reprehensibility, $\underline{F}(1,440)=9.18, \underline{p}=.003$. For the conditions in which defendants proffered concessions, excuses, or refusals, none of the simple effects tests of reprehensibility within defendant status were significant, all $\underline{\mathrm{Fs}}<1.78, \underline{\mathrm{ns}}$.

I performed a 4 (Account) X 2 (Injury Severity) X 2 (Reprehensibility) X 2 (Corporate Status) ANOVA on the non-economic damage awards. For non-economic awards, there were significant main effects for both injury, $\underline{F}(1,431)=29.65, \underline{p}<.001, \eta^{2}$ $=.06$, and reprehensibility, $\underline{\mathrm{F}}(1,431)=4.91, \underline{\mathrm{p}}<.03, \eta^{2}=.01$. Participants awarded higher pain and suffering awards when injuries were more severe $(\underline{M}=512,878, \underline{S D}=$ $19,074)$ as opposed to less severe $(\underline{M}=293,481, \underline{\mathrm{SD}}=19,179)$. Jurors also awarded higher damages in cases in which the defendant was highly reprehensible $(\underline{M}=416,273$, $\underline{\mathrm{SD}}=19,211)$ rather than less reprehensible $(\underline{\mathrm{M}}=390,085, \underline{\mathrm{SD}}=19,046)$. 
There was also a significant two-way interaction of Status X Account, $\underline{F}(3,431)=$ $3.10, \underline{p}<.03, \eta^{2}=.02$ (see Table E2 for means). When defendants proffered excuses, jurors' awarded higher pain and suffering awards against individual defendants than they did against corporate defendants, $\underline{F}(1,431)=6.75, \underline{p}=.01$. Defendant status did not influence jurors' pain and suffering awards when defendants proffered concessions, justifications, or refusals, all $\underline{\mathrm{Fs}}<2.0, \underline{\mathrm{ns}}$.

This two-way interaction was qualified by a significant 3-way interaction of Status X Reprehensibility X Account, $\underline{F}(3,431)=3.64, \underline{p}<.01, \eta^{2}=.03$ (see Table E3 for means). Defendant status and reprehensibility interacted to influence pain and suffering awards when defendants proffered excuses or justifications. When individual defendants proffered excuses, defendant reprehensibility did not influence awards, $\underline{\mathrm{F}}<1, \underline{\mathrm{ns}}$; however, when the defendant was a corporation and offered an excuse, jurors did give higher pain and suffering awards when reprehensibility was high than when it was low, $\underline{F}(1,431)=11.23, \underline{p}<.001$. A different pattern of effects occurred when defendants offered justifications. When individual defendants proffered justifications, jurors gave higher non-economic awards when reprehensibility was high than when it was low, $\underline{\mathrm{F}}(1$, $431)=4.52, \underline{p}<.04$. When corporate defendants proffered justifications, reprehensibility did not influence pain and suffering awards, $\underline{\mathrm{F}}<1$, $\underline{\text { ns. }}$. Reprehensibility and defendant status did not interact to influence pain and suffering awards when defendants offered concessions or refusals, all $\underline{\mathrm{F}} \mathrm{s}<1.94, \underline{\mathrm{ns}}$.

\section{Punitive Damages}

I performed a final 4 (Account) X 2 (Injury Severity) X 2 (Reprehensibility) X 2 (Corporate Status) ANOVA on the punitive awards. For punitive damages, there was a 
significant main effect for reprehensibility, $\underline{F}(1,358)=4.81, \underline{p}<.03, \eta^{2}=.01$. Jurors awarded higher punitive damages when the defendant was more reprehensible $(\underline{M}=$ $629,494, \underline{\mathrm{SD}}=59,842)$ rather than less reprehensible $(\underline{\mathrm{M}}=432,822, \underline{\mathrm{SD}}=60,722)$. No interactions were significant.

\section{Effects of Stipulating Negligence}

A 2 (Status) X 2 (Account) X 2 (Stipulation) ANOVA was performed on each economic damages, non-economic damages, and punitive damages to analyze the data from the dangling control conditions. There were no significant effects of these variables for the punitive damage awards.

Economic damage awards. The analysis of economic damages demonstrated no significant main effects, but the 3-way interaction of Status X Account X Stipulation was significant, $\underline{F}(1,111)=5.79, \underline{p}<.02, \eta^{2}=.05$ (see Table E4 for means). For individual defendants, account did not interact with negligence stipulations to influence economic damage awards, both $\underline{\mathrm{F}}<2.40$, $\underline{\text { ns }}$. In contrast, when corporate defendants offered concessions, jurors awarded lower economic damages when the defendant stipulated negligence than when they did not, $\underline{F}(1,111)=6.13, \underline{p}<.02$. When corporate defendants offered excuses, stipulation of negligence did not influence economic awards, $\underline{\mathrm{F}}<1$, $\underline{\mathrm{ns}}$.

Non-economic damage awards. The ANOVA performed on the non-economic damages also demonstrated no significant main effects. There was a significant two-way interaction of Status X Account, $\underline{\mathrm{F}}(1,108)=7.56, \underline{\mathrm{p}}<.007, \eta^{2}=.07$ (see Table E5 for means). When defendants proffered concessions, jurors' awarded higher pain and suffering awards when the defendant was a corporation than when it was an individual, 
$\underline{F}(1,108)=6.68, \underline{p}<.02$. When defendants proffered excuses, defendant status did not influence non-economic damage awards, $\underline{F}(1,108)=1.70$, ns.

Analyses of the non-economic damage awards also revealed a significant Status X Stipulation interaction, $\underline{F}(1,108)=6.36, \underline{p}<.01, \eta^{2}=.06$ (see Table E6 for means). When individual defendants stipulated negligence, jurors made lower non-economic damage awards than when they did not stipulate negligence, $\underline{\mathrm{F}}(1,108)=4.02, \underline{\mathrm{p}}<.05$. The stipulation of negligence did not influence pain and suffering awards levied against corporate defendants, $\underline{\mathrm{F}}(1,108)=2.47$, ns. If anything, there was a trend toward jurors' levying higher damages against corporate defendants that stipulated negligence in comparison with corporate defendants that did not.

Finally, there was a significant two-way Account X Stipulation interaction, $\underline{F}(1,108)=4.53, \underline{p}<.04, \eta^{2}=.04$ (see Table E7 for means). Although none of the simple effects tests met traditional levels of significance, there was a trend for jurors to award higher non-economic damages when defendants proffered concessions but did not stipulate negligence than when defendants both conceded and stipulated negligence, $\underline{\mathrm{F}}(1$, $108)=2.90, \underline{p}<.10$. Negligence stipulation did not influence damage awards when defendants proffered excuses, $\underline{F}(1,1,08)=1.74$, $\underline{\text { ss. }}$.

\section{Discussion}

Previous studies have demonstrated that injury severity, defendant reprehensibility, and the defendant's status as an individual or corporation influences jurors' damage award decisions. This study examined whether the account given by defendants also influences those award decisions and how accounts proffered by defendants interact with the previously mentioned factors. Among others, this study 
addressed the following questions: Does account type affect damage award decisions and if so, does it affect compensatory and punitive damages differently? Will the effect of account type be moderated by the severity of the plaintiff's injuries or the defendant's reprehensibility? Will certain accounts be more effective dependent upon whether the defendant is a corporation or an individual?

\section{Injury Severity}

In congruence with past research (Bovbjerg, et al., 1991; Cather et al., 1996), injury severity influenced damage awards. I predicted that injury severity would affect both compensatory and punitive awards. Injury severity did significantly affect both types of compensatory award (economic and non-economic). In the analysis of economic damages, which consisted primarily of medical expenses and lost wages, jurors gave higher awards when the plaintiff suffered more severe injuries. Not only was this finding expected, but also it is legally appropriate. In an actual case, plaintiffs who suffer more severe injuries would typically require more money to cover the cost of higher medical bills and longer periods of time without working. Equally consistent with legal intentions is the finding that jurors awarded higher non-economic (pain and suffering) awards to more severely injured plaintiffs. It is reasonable that participants would award higher damages for pain and suffering to plaintiffs who have endured more severe injuries. The greater the injury, the greater the suffering. If the suffering is greater, then the compensation for that suffering should also be greater.

A caveat concerning the influence of injury severity on economic damage awards must be noted. As previously stated, injury severity influenced economic damages in this study. Researchers both predicted and expected this finding. However, some differences 
between this study and actual cases exist which make this finding more noteworthy. In the present study, researchers provided participants with specific amounts as to what the plaintiff was requesting for each of the economic components (e.g., medical expenses, lost wages). The amount requested by the plaintiff remained constant regardless of the injury condition. For example, within a given scenario, the requested amount for medical expenses was the same, whether the description consisted of a severely injured plaintiff or a mildly injured plaintiff. Had the jurors merely been awarding the amount requested, thereby compensating the plaintiff for the losses suffered, there should be no difference in the economic damage category between awards for severely injured plaintiffs and mildly injured plaintiffs. That, however, is not what was shown. Mock jurors adjusted the numbers given to them based upon the degree of plaintiff injury.

I also predicted that injury would influence punitive awards. Contrary to that prediction, injury severity did not exhibit an effect on punitive damages. Participants did not choose to punish the defendants with higher awards based on the fact that the plaintiff was severely injured which is a legally appropriate decision. These findings provide evidence that jurors did consider the plaintiff's injuries when it was legally appropriate, but did not consider injury severity when it was not legally appropriate. Although research on this topic has been mixed in the past, these findings are encouraging. Injury severity did not interact with account type or any other manipulated variable. This held true across all damage categories. Although jurors awarded larger amounts to severely injured plaintiffs, as opposed to mildly injured plaintiffs, the account proffered by the defendant, defendant status, and defendant reprehensibility did not moderate the influence of injury severity on compensatory awards. 


\section{Defendant Reprehensibility}

The law allows jurors to consider defendant reprehensibility only when making punitive award decisions. I predicted that defendant reprehensibility would influence both compensatory and punitive award decisions. In accordance with legal intentions but in opposition to my prediction, defendant reprehensibility did not influence economic damage awards. In accordance with both legal intentions and my hypothesis, jurors did consider defendant reprehensibility when making punitive award decisions. In both of these situations, jurors based their decisions on the factors deemed appropriate by the law. Defendant reprehensibility, however, did influence jurors inappropriately when making pain and suffering award decisions. Pain and suffering awards are the compensatory awards in which the most variability is expected. Our system gives jurors the difficult task of applying a dollar amount to fairly compensate a plaintiff for a vague construct. Although in this study jurors were given an amount requested by the plaintiff, jurors know that that number is not based upon hard figures in the same way that medical expenses are. As has been found in previous research, jurors inappropriately considered defendant reprehensibility when making pain and suffering awards (Cather et al., 1996, Carpenter et al., 2000).

In addition to the main effects of reprehensibility found in this study, reprehensibility also influenced awards by interacting with other variables. The effects of defendant reprehensibility were apparent when defendants accounted for their behavior using either justifications or excuses. For both economic and non-economic damages, justifications resulted in lower damage awards when offered by low reprehensibility individuals rather than high reprehensibility individuals. Additionally, in non-economic 
awards, excuses resulted in lower awards when provided by less reprehensible corporations as opposed to more reprehensible corporations.

In offering justifications and excuses, defendants are not merely providing an apology or denying fault as in concessions and refusals. With justifications and excuses, the defendant attempts to provide an explanation for the wrongdoing. More specifically, justifications attempt to shift the blame from one party to another and excuses attempt to reduce the perceived responsibility of the excuse-provider (Snyder \& Higgins, 1988).

Because jurors hold corporations to a higher standard than individuals (Hans \& Ermann, 1989), defendant characteristics other than corporate status may have more impact on awards for individual defendants than for corporate defendants. The mere fact that the defendant was a corporation may outweigh other factors in the minds of the jurors. This may explain why reprehensibility did not influence awards against corporate defendants who proffered justifications. Therefore, there would be no effect for defendant reprehensibility for corporate defendants who offered justifications. In other words, jurors may not accept this blame-shifting from any corporation, regardless of the offensiveness of the defendant's behavior. However, for individual defendants, that may not be the case. If the defendant is an individual, jurors may rely on additional defense characteristics, such as defendant reprehensibility, when making damage award decisions. Given those circumstances, it is both logical and intuitive that jurors would believe an individual's justification more readily when the individual's actions were less as opposed to more offensive.

Reprehensibility also influenced awards when corporations offered excuses, but not when individuals offered excuses. The goal of an excuse is to make the provider of 
the excuse appear less responsible for the behavior committed or the results of that behavior. Being perceived as less responsible should lead to a reduction in the amount of damage awards levied against the defendant. A possible explanation for this finding may be that jurors view individual defendants as less responsible for wrongdoing than corporate defendants, regardless of reprehensibility level. Reprehensibility, then, would not influence how excuses proffered by individuals are perceived thereby not affecting amounts awarded against the individual defendants proffering excuses. Defendant reprehensibility, however, would affect corporate defendants proffering excuses.

Corporate defendants would face more difficulty than individuals in providing jurors with a convincing excuse that would lead to a reduced perception of responsibility. As a result, the effectiveness of an excuse provided by a corporation would be moderated by the reprehensibility of the defendant's actions. In situations in which the corporation did not act offensively, jurors may accept the excuse leading to a reduction in damage awards. However, when the corporation did act offensively, jurors may reject the excuse and award higher damages.

Interestingly, jurors did not look to defendant reprehensibility to help with award decisions when individuals proffered concessions, excuses, or refusals. In the same manner, jurors did not look to defendant reprehensibility to help with award decisions when corporations proffered concessions, justifications, or refusals. Further studies could investigate why these trends were not consistent across account conditions. In any event, individual defendants should carefully consider reprehensibility level before deciding to respond to civil litigation using a justification. Similarly, corporate defendants should 
carefully consider the reprehensibility of their actions before choosing to respond to civil litigation using an excuse.

\section{$\underline{\text { Corporate Status }}$}

Previously, researchers demonstrated that a defendant's status as an individual or a corporation directly influences the damage awards levied against them (Hans \& Ermann, 1989; MacCoun, 1996). This is true regardless of whether status is a legally appropriate consideration (MacCoun, 1996). I predicted that a defendant's corporate status would influence both compensatory and punitive damage awards. Surprisingly, the present study found no main effects for corporate status. This is not to say that the corporate status of the defendant had no influence on damage awards within this study. Corporate status interacted with both account type and reprehensibility to influence damage awards. I also predicted that concessions and excuses would be more effective for individuals than for corporations. Although I found no effects of corporate status within concessions, results did indicate that excuses lead to higher pain and suffering awards when offered by an individual rather than a corporation.

The interactions found in this study, in congruence with previous studies, indicate that jurors hold individuals and corporations to different standards. In pain and suffering awards, excuses resulted in higher awards when given by an individual than when given by a corporation. As previously discussed, this interaction was qualified by an interaction including defendant reprehensibility. However, in light of the previous explanation, it would be expected that excuses may be more effective for individual defendants than for corporate defendants. Because jurors expect more foresight from corporations, the responsibility-reducing effects of excuses may be greater for individuals 
than for corporations. For this reason, jurors receiving an excuse from an individual may accept the excuse and reduce damage awards according. However, jurors given an excuse by a corporation may be less accepting of the excuse resulting in little or no change in their award decision. Thus, awards against individuals proffering excuses would be expected to be less than awards against corporations proffering excuses. This is not, however, what was found within this study. I believe that within this study, these results were due to a higher order interaction involving reprehensibility which qualifies these findings.

\section{$\underline{\text { Account }}$}

As a result of prior research, injury severity, defendant reprehensibility, and a defendant's corporate status are known to influence damage awards. Additionally, research has also shown that different accounts are perceived differently and that certain accounts are more effective than others. Research has also shown that both personal and situational factors affect how an account is perceived. I predicted that account type would not influence compensatory awards, but would exert an influence on punitive awards. Contrary to those predictions, account did influence compensatory awards, but did not influence punitive awards. There were no main effects for account type for the three types of damage awards found in this study. However, this study demonstrated, for the first time, that the account given by a defendant interacts with other case factors to exert an influence on compensatory damage awards.

For both excuses and justifications, the level of defendant reprehensibility influenced damage awards. If an individual defendant intends to explain negligent behavior using a justification or a corporate defendant intends to explain negligent 
behavior using an excuse, the reprehensibility of the defendant's behavior should be considered. When defendants provided concessions and refusals, the level of defendant reprehensibility did not influence awards. However, when defendants provided excuses and justifications, low reprehensibility defendants received lower damage awards against them than high reprehensibility defendants. This proved true for both economic and noneconomic awards and for both individuals and corporations. These findings illustrate the need for defendants to examine all case-relevant factors when deciding how to explain negligent behavior.

\section{Defense Stipulation}

I collected data under conditions in which defendants' stipulated negligence to determine whether such a stipulation, combined with either a concession or an excuse would reduce damages awarded against them. It was anticipated that corporate status may also influence awards in those conditions; therefore, the corporate status of the defendant was manipulated as well. I predicted that an apologetic account would be more effective when combined with a stipulation of negligence. The results indicate that whether stipulations are beneficial to the defendant depend upon the account with which they are combined and the status of the defendant proffering the stipulation.

For economic damage awards, there were no differences in damage awards for individuals, regardless of whether a concession or an excuse was given. Additionally, whether the individual stipulated negligence did not influence awarded amounts. When corporations explained their behavior using excuses, defense stipulations and jury decisions did not lead to differences in awarded amounts. However, when corporations explained their behavior using concessions, a defense stipulation led to lower awards than 
when negligence was not stipulated. This result can be easily explained. Once a concession is given, there is then no reason not to stipulate negligence. By providing the concession, defendants are accepting responsibility and admitting fault. To then not take that admission to the final step and stipulate negligence would discredit the apology provided. Jurors will most likely find an apology more sincere if the corporation follows the apology with a stipulation of negligence. If following an apology, the corporation allows the negligence decision to go to the jury, the opportunity for the apology to appear as merely a defense strategy is increased. If instead, the corporation offers an apology and accepts responsibility in the form of admitting negligence, the apology will appear as less a strategic maneuver and more a sincere apology. This same trend was found for pain and suffering awards. When a concession was combined with a stipulation of negligence the award tended to be lower than when a concession was combined with a jury decision. Unfortunately, I did not conduct ratings of defendant trustworthiness that would allow for a test of this explanation; however, this may be a fruitful avenue for future research.

Differences in pain and suffering awards were also apparent when individuals and corporations offered concessions to explain their behavior. Accounting for behavior using a concession led to lower damage awards for individuals than for corporations. Because of the differences in how corporations and individuals are viewed, jurors may be more accepting of an apology from an individual. With an individual there is only one person, thus there is a lesser expectation of foresight than with a corporation which is composed of many individuals (Hans \& Ermann, 1989). For this reason, an apology from an individual may seem more sincere and less contrived than an apology coming 
from a corporation. Jurors may regard apologies offered by corporations more suspiciously than those offered by individuals, thereby leading to lower damage awards when an individual defendant apologizes as opposed to a corporate defendant apologizing.

For individuals, stipulating negligence produced lower awards than allowing a jury to decide negligence. On the contrary, for corporate defendants, there was a trend for stipulating negligence to produce higher awards than a jury decision. Therefore, holding account constant, individuals appear to benefit more than corporations by using negligence stipulations. This may be another effect of jurors holding corporations to a different standard than they hold individuals. When a negligence stipulation is offered by an individual, jurors may perceive that stipulation with less skepticism than had it been offered by a corporation.

These results indicate that the decision whether to offer a stipulation and an apology should be based upon the corporate status of the defendant. If the defendant is an individual, stipulating negligence and offering an apology may prove beneficial. When the defendant is a corporation, a better strategy may be to allow a jury to decide negligence. If a defendant chooses to use a concession, it would be most beneficial to use the concession in conjunction with a stipulation of negligence.

Probably the most unexpected findings were that negligence stipulations had no significant effects on punitive awards. Because lawmakers designed punitive awards to punish defendants, it is surprising that jurors do not punish defendants who admit negligence differently than those who deny negligence. Further research could examine 
whether negligence stipulations influence punitive awards under circumstances not tested here, such as with high injury plaintiffs and high reprehensibility defendants.

\section{Conclusion}

This study provides limited support to the argument that jurors have difficulty compartmentalizing different types of damages and considering only legally appropriate factors when making each award decision. Findings in this study are consistent with prior research showing that certain extra-legal factors influence jurors' award decisions (Cather et al., 1996). More interestingly, however, is the manner in which the accounts given by the defendant influenced the awarded amounts. Concessionary accounts did not demonstrate the reduction in punitive damages, as was predicted, and excuses and justifications resulted in interesting trends under many different circumstances. This is especially important because based on several high profile cases, such as those previously reviewed, justifications appear to be a strong and common defense strategy. Justifications provide defendants with a way to apologize without actually admitting fault. These findings indicate that under certain circumstances using such a strategy may be beneficial. At other times, however, such a strategy may not be a defendant's wisest option.

The findings in this study also give rise to many new questions. Stipulation comparisons demonstrated once again that jurors perceive individual defendants differently than corporate defendants. It would be interesting to many in the legal community to determine what other factors interact with those tested here and in what other circumstances negligence stipulations are beneficial. 
This experiment addressed several questions that had not been addressed in legal and psychological research. Although there is vast research examining the perceptions and effectiveness of accounts, research extending the account literature into legal contexts is sparse. This research examined not only how jurors perceived different accounts offered by defendants in civil cases, but also how those perceptions influenced damage awards. These findings also establish the case-specific facts, such as the degree of plaintiff injury and the corporate status and reprehensibility of the defendant, that outline when one account should be preferred over another account.

Limitations to this research exist. Although participants were jury-eligible community members, the cases were presented by way of vignette. Testing the scenarios in a more realistic setting, such as through video or live presentation would be valuable in determining the robust nature of these findings. Additionally, the analysis of negligence stipulations was limited, as stipulations were not the primary focus of this study. Future studies utilizing a fully-crossed design could generate interesting and useful information regarding negligence stipulations. These studies would provide a more in-depth understanding of the benefits of offering such stipulations and when stipulations would be advantageous to defendants.

Furthermore, defense strategies often consist of a combination of accounts rather than a single account. This study provides initial information as to how single accounts influence damage awards, but offers no data regarding compound accounts. Further research in this area could examine the specific factors involved in each type of account, how those factors are perceived within a legal context, and how factors from different accounts may be combined to produce effective compound accounts. Research in this 
area may demonstrate that individual account strategies are less effective than a compound strategy formed by blending several accounts. 
Benoit, W. L. \& Drew, S. (1997). Appropriateness and effectiveness of image repair strategies. Communication Reports, 10(2), 153-163.

Blumstein, P. W., Carssow, K. G., Hall, J., Hawkins, B., Hoffman, R., Ishem, E., Maurer C. P., Spens, D., Taylor, J., \& Zimmerman, D. L. (1974). The honoring of accounts. American Sociological Review, 39, 551-566.

Breast implant lawsuit pits Elko woman against Dow Chemical. (1995, October 25). The Las Vegas Review-Journal, p. 11B.

Bovbjerg, R., Sloan, F., Dor, A., \& Hsieh, C. (1991). Juries and justice: Are malpractice and other personal injuries created equal? Law and Contemporary Problems, 54, 5-42.

Carpenter, T. R., Kovera, M. B., \& Moran, G. (2000, March). Countering the effects of extra-legal factors in damage award decisions. Poster session presented at the biennial meeting of the American Psychology-Law Society, New Orleans, LA.

Cather, C., Greene, E., \& Durham, R. (1996). Plaintiff injury and defendant reprehensibility: Implications for compensatory and punitive damage awards. Law and Human Behavior, 20 (2), 189-205.

Chin, A. \& Peterson, M. A. (1985). Deep Pockets, Empty Pockets: Who Wins in Cook County Jury Trials. Santa Monica, CA: RAND Corporation.

Cody, M. J. \& McLaughlin, M. L. (1988). Accounts on trial: Oral arguments in traffic court. In C. Antaki (Ed.), Analysing everyday explanations: A casebook of methods. (pp. 113-126). London: SAGE Publications.

Conlon, D. E. \& Ross, W. H. (1997). Appearances do count: The effects of outcomes and explanations on disputant fairness judgements and supervisory evaluations. The International Journal of Conflict Management, 8(1), 5-31.

Dow Chemical Company v. Charlotte Mahlum, 970 P.2d 98 (Sup. Ct. Nev. 1998).

Felson, R. B. \& Ribner, S. A. (1981). An attributional approach to accounts and sanctions for criminal violence. Social Psychology Quarterly, 44(2), 137-142.

Gonzales, M. H. (1992). A thousand pardons: The effectiveness of verbal remedial tactics during account episodes. Journal of Language and Social Psychology, $\underline{11}(3), 133-151$. 
Gonzales, M. H., Haugen, J. A., \& Manning, D. J. (1994). Victims as narrative critics: Factors influencing rejoinders and evaluative responses to offenders' accounts. Personality and Social Psychology Bulletin, 20(6), 691-704.

Gonzales, M.H., Manning, D. J., \& Haugen, J. A. (1992). Explaining our sins: Factors influencing offender accounts and anticipated victim responses. Journal of Personality and Social Psychology, 62(6), 958-971.

Greene, E., Johns, M., \& Smith, A. (in press). The effects of defendant conduct on jury damage awards. Journal of Applied Psychology.

Hans, V. P. \& Ermann, M. D. (1989). Responses to corporate versus individual wrongdoing. Law and Human Behavior, 13 (2), 151-166.

Hiner v. Bridgestone/Firestone, Inc., 978 P.2d 505 (Sup. Ct. Wash. 1999).

Horowitz, I. \& Bordens, K. (1990). An experimental investigation of procedural issues in complex tort trials. Law and Human Behavior, 14, 269-285.

Hupka, R. B., Jung, J., \& Silverthorn, K. (1987). Perceived acceptability of apologies, excuses and justifications in jealousy predicaments. Journal of Social Behavior and Personality, 2(3), 303-313.

Insolia v. Phillip Morris, Inc., 186 F.R.D. 535 (W.D. Wis. 1998).

Koenig, T. \& Rustad, M. (1993). The quiet revolution revisited: An empirical study of the impact of state tort reform of punitive damages in products liability. The Justice System Journal, 16, 21-44.

MacCoun, R. J. (1996). Differential treatment of corporate defendants by juries: An examination of the "deep-pockets" hypothesis. Law and Society Review, 30 (1), 121161.

McLaughlin, M. L., Cody, M. J., \& French, K. (1990). Account-giving and the attribution of responsibility: Impressions of traffic offenders. In Cody, M. J. (Ed.) \& McLaughlin, M. L. (Ed.), The psychology of tactical communication. Monographs in social psychology of language. (pp. 244-267). Cleveland, England: Multilingual Matters, Ltd.

Marcus, N. (1998, October 16). Jury picked for historic statewide smokers' trial. Sun-Sentinel Ft. Lauderdale, p. 3B.

Riordan, C. A., Marlin, N. A., \& Gidwani, C. (1988) Accounts offered for unethical research practices: Effects on the evaluations of acts and actors. The Journal of Social Psychology, 128(4), 495-505. 
Riordan, C. A., Marlin, N. A., \& Kellogg, R. T. (1983). The effectiveness of accounts following transgression. Social Psychology Quarterly, 96(3), 213-219.

Rodriguez v. Bridgestone/Firestone, Inc. Civil-M-01-165. (United States District Court for the Southern District of Texas, 2001). Trial testimony of Bridgestone/Firestone Chief Executive Officer, John Lampe.

Schoenbach, P. (1980). A category system for account phases. European Journal of Social Psychology, 10(2), 195-200.

Snyder, C. R. \& Higgins, R. L. (1988). Excuses: Their effective role in the negotiation of reality. Psychological Bulletin, 104(1) 23-35.

Wasserman, D. T., \& Robinson, J. N. (1980). Extra-legal influences, group processes, and jury decision-making: A psychological perspective. North Carolina Central Law Journal, 12, 96-159.

Wissler, R. L., Evans, D. L., Hart, A. J., Morry, M. M., \& Saks, M. J. (1997). Explaining "pain and suffering" awards: The role of injury characteristics and fault attributions. Law and Human Behavior, 21 (2), 181-207. 


\title{
The following excerpt provides information about a civil court case. Please read the information carefully and answer the questions that follow.
}

\author{
West v. Peri-Care Inc (Raymond Perry)
}

James West, a 72 year-old stroke victim, resided in Montrose Bay Health Care Center, a nursing home in Montrose, Alabama. As a result of his stroke, Mr. West was unable to speak or comprehend speech, suffered memory loss, and had significant paralysis of his right side. Two months after his arrival at Montrose Bay, Mr. West's condition had deteriorated to the point that he was transferred to the hospital.

Low injury severity: At that time, doctors discovered that he seemed to be slightly malnourished and suffering from an infection. He also appeared to have a few small bedsores indicating that he had not been turned as often as he should have been. Mr. West was in the hospital for two days and it was two more weeks before he returned to the state he was in when he arrived at Montrose Bay.

High injury severity: At that time, doctors discovered that he was badly malnourished and suffering from a systemic infection including a gangrenous bedsore measuring 10 inches in diameter. Mr. West was in intensive care for three weeks. His stroke symptoms worsened and a result of the malnutrition and infection and his health will never return to the state it was when Mr. West arrived at Montrose Bay.

Mr. West's wife, Audrey, filed a lawsuit against Peri-Care Inc.(Raymond Perry), owner of the Montrose Bay Health Care Center, alleging medical negligence in the care of her husband. Mrs. West testified that she had been hospitalized during the same period for cancer that she was unaware of the level of care that her husband was receiving although she had complained of a foul order in his room.

Low Reprehensibility: Other evidence at trial included records from the nursing home. A monthly data sheet indicated when Mr. West was turned and when he was fed. Some of the dates were clearly in error, indicating that Mr. West was cared for on days when he was not in the care of the nursing home. Apparently, the nursing staff did not keep clear records and mistakenly indicated that Mr. West had been cared for when he was not.

High Reprehensibility: Other evidence at trial included records from the nursing home. A monthly data sheet indicated when Mr. West was turned and when he was fed. Many of the dates were clearly in error, indicating that Mr. West was cared for on days when he was not in the care of the nursing home. There was strong evidence that the nursing staff routinely falsified records, indicating that they cared for Mr. West when they did not. Testimony revealed that this problem had been reported to management on numerous occasions, but no action was ever taken to ensure that the nurses did not falsify the records. The nursing home staff failed to evaluate and treat Mr. West's bedsores.

Nursing home records also indicated that the facility was short-staffed, well below federal guidelines. In addition, a nurse and ex-employee of the nursing home provided evidence of other nurses smoking marijuana and sleeping on the job. According to this witness, management had been alerted to these problems as well, but once again, had done nothing to prevent the behavior. She also testified that patients were not helped to 
the bathroom nor were they catheterized so they often urinated and defecated in their bed and were forced to lie in the excrement for up to two days.

Trial testimony also focused on the damages incurred by the Wests. Mrs. West's attorneys submitted as evidence the following documents: medical bills from James West's final hospital stay totaling $\$ 24,856$ and a bill for nursing home care totaling $\$ 28,650$. The Wests' attorneys are also seeking $\$ 500,000$ for pain and suffering.

Peri-Care (Mr. Perry) responded in the following manner:

Concession: Peri-Care (I) recognizes that Mr. West's injuries were a direct result of the poor care he received at our facility and we are truly sorry for his suffering. Our company (I) was horrified by the incident and immediately took precautions to ensure that such incidents would not occur again at our facility. In addition, any employees involved in falsification of records have been dismissed. We have instituted a frequent evaluation system to ensure that our employees are performing their duties properly and effectively. In addition, we perform regular random checks to ensure that patient charts are completed truthfully and accurately.

Excuse: Peri-Care (I) is truly sorry for the injuries that Mr. West suffered while in the care of my facility. The nurse who primarily cared for Mr. West had been working double-shifts for the past three weeks due to the nursing shortage which apparently interfered with her ability to care for her patients. Because her records were not accurate, I was unable to detect that Mr. West was not receiving adequate care.

Justification: Peri-Care (I) is sorry that Mr. West's condition worsened during his time at our facility. However, our staff recognized that Mr. West's health was declining and Mr. West was transferred to the hospital before his condition got too serious. It is not uncommon or especially serious for persons in Mr. West's condition to develop such infections. As soon as Mr. West's condition was realized, we sent him to a hospital where he could receive more immediate treatment.

Refusal: Peri-Care regrets Mr. West's condition, but maintains that our facility is not responsible for his poor health. Our facility provides a high standard of care and none of our patients are neglected. Mr. West was not well and unfortunately patients in his condition are often plagued by problems of this type despite excellent care. 
The following excerpt provides information about a civil court case. Please read the information carefully and answer the questions that follow.

Carl and Pearl Jeansonne v. Anderson Corporation (Robert Anderson)

Jeansonne v. Anderson Corporation (or Robert Anderson) is a lawsuit concerning injuries suffered as a result of an automobile accident. Carl and Pearl Jeansonne claim that Charles Landau, an employee of the Anderson Corporation (Robert Anderson) was making a delivery for the company when he negligently caused an accident resulting in injuries to Carl Jeansonne. Charles Landau, a driver for Anderson's Corporation (Mr. Anderson), was operating a semi tractor truck that was attached to a large trailer loaded with asphalt. Entering a highway construction site, Mr. Landau lost control of his tractortrailer, crossed two lanes of traffic, and crashed into the median. The front axle from his truck became airborne and struck the front windshield of a truck being driven by the plaintiff, Carl Jeansonne. Mr. Jeansonne was injured. The roadway was clear and dry.

Low Reprehensibility: Two witnesses stated that the plaintiff did not appear to be violating the speed limit immediately before the accident. Both agreed that the driver apparently lost control of his vehicle as he was entering the construction area. A review of Mr. Landau's driving record revealed he has received one speeding ticket over the previous 6 years, but has never been cited for any other traffic violations. Mr. Anderson performed thorough checks before hiring Mr. Landau. In order to be employed by Mr. Anderson, a driver must have 5 years driving experience with no accidents, no more than two speeding tickets over the past 10 years, and must pass a drug screening. Each driver is also required to complete several training courses before taking a truck off the property.

High Reprehensibility: Two witnesses estimated that the plaintiff was driving 15-20 mph over the speed limit for the construction zone. An expert for the plaintiffs stated that in his professional opinion, the tractor-trailer was traveling too fast for the conditions and as a result, the driver lost control of his vehicle. In addition, the expert testified that the driver did not use the proper braking technique which resulted in the severity of the accident. A review of Mr. Landau's driving record revealed that over the previous 6 years he has been convicted of 3 speed related offenses and a DUI. The Anderson Corporation performed no checks of Mr. Landau's driving record before hiring him and did not require any training or driving safety courses.

Low Injury Severity: Mr. Jeansonne sustained a concussion--a brief loss of consciousness - as well as an injury to the cervical spine and a soft tissue injury to the neck resulting in muscle spasms. He is fully mobile but complains of recurrent back and neck pain. He missed a month and a half of work recovering from this injury. He continues to receive massage therapy and chiropractic care and it is anticipated that he may not be completely healed for another 6 months.

High Injury Severity: Mr. Jeansonne suffered multiple fractures of the skull and contusions in the brain and was in a coma upon his arrival to the hospital. After several weeks, he emerged from the coma, but remained bedridden, nonverbal, and mute. Mr. Jeansonne continues to receive physical, occupational, and speech therapy. He remains in state of very low functioning. It is anticipated he will remain totally dependent throughout the remainder of his life. 
Under laws of vicarious liability, employers are responsible for any actions of their employees during the time the employees are on duty. The law clearly states that if an employee causes an accident while in the commission of work duties, the employer is ultimately responsible for any damages as a result of that accident.

Attorneys for Mr. Jeansonne are requesting the following amounts in damages: $\$ 32,517$ in medical expenses, $\$ 230,000$ in past and future lost wages, and $\$ 600,000$ in pain and suffering.

In response to the lawsuit brought by the Jeansonne's, the Anderson Corporation (Mr. Anderson) has made the following statement:

Concession: Our company (I) understands that one of our employees cased an accident resulting in injuries to Mr. Jeansonne. The Anderson Corporation (I) accepts full responsibility for this horrible accident and we are truly sorry that this has occurred. This incident has caused us to reevaluate and strengthen our already stringent safety measures, so that this type of incident will not be repeated."

Excuse - I understand that my employee caused an accident resulting in injuries to Mr. Jeansonne. I am truly sorry that such an incident occurred. However, the construction zone in which the accident happened was not well marked and my driver suddenly came upon an uneven patch of road. The road was wet and when he applied the brakes, the truck began to skid. Despite his best attempts, he was unable to control the truck and prevent the accident.

Justification - Our company (I) understands that our driver was involved in an accident resulting in injuries to Mr. Jeansonne. However, our driver handled the truck the best he could and the accident could have been much worse. There were several other cars in the vicinity and our driver acted quickly to avoid a colliding with any other cars.

Refusal - The Anderson Corporation (I) understands that Mr. Jeansonne has suffered some serious injuries, but we are not responsible for those injuries. Our company (I) holds it's drivers to the strictest safety regulations and has made every attempt to prevent accidents. This accident occurred in an unsafe area and was completely beyond our driver's control. Neither our driver nor our company was negligent in any way. 
The following excerpt provides information about a civil court case. Please read the information carefully and answer the questions that follow.

Herman v. Morgan Chemical Corporation.(Robert Morgan)

Morgan Chemical Corporation (Robert Morgan) hired Sandra Herman, age 34, as an independent contractor to demonstrate and sell its products. While demonstrating SunClean, an all-purpose cleaner, Mrs. Herman suffered a coughing fit and developed a fever and breathing problems. She consulted several doctors and an allergist. She underwent several expensive treatments and was placed her on steroid- and cortisone-based drugs that gradually improved her breathing but caused her to gain over 60 pounds. Later, her doctors began to suspect a connection between her asthma and her work. Her doctors learned that Sun-Clean contained a caustic, sodium hydroxide. Mrs. Herman was diagnosed as suffering from "occupational asthma", meaning asthma caused by exposure to chemicals in the workplace. At that time, Mrs. Herman ended her employment with Morgan Chemical Corporation (Robert Morgan).

Low injury severity: She was advised that her symptoms would likely flare up and that her condition would worsen when she was tired or feeling stressed. They advised her to work no more than 20 hours per week at her new job.

High injury severity: She was advised that her condition would worsen as she aged and that she would be required to have weekly respiratory therapy for the rest of her life. In addition, it is likely that Mrs. Herman will develop lung cancer and emphysema at a relatively early age. At this point, she has been advised to work no more than 20 hours per week at her new job. Within the next ten years, she will probably be completely unable to work due to breathing difficulties.

Mrs. Herman and her husband filed a complaint against Morgan Chemical (Robert Morgan) asserting that Morgan Chemical (he) was negligent in not providing sufficient warnings about the dangers inherent in use of its product. During a two-day training period, Sunshine instructed Mrs. Herman about the company's products and personnel, but no part of the training concerned the potential hazards or safe use of the products.

The Sun-Clean label stated: "SUN CLEAN is safe to use". In larger print, the label stated that Sun-Clean "CONTAINS NO ACIDS, CAUSTICS, AMMONIA, ALIPHATIC OR AROMATIC SOLVENTS". The label stated that Sun-Clean met the "operating standards" of the Occupational Safety and Health Administration (OSHA). It did not warn of the dangers of inhaling Sun-Clean vapors.

Low Reprehensibility: John Morgan designed the Sun-Clean label by copying information from product labels of other manufacturers. A chemist employed by $\mathrm{Mr}$. Morgan had the responsibility to review the labels. He did not recommend any label changes.

High Reprehensibility: John Morgan designed the Sun-Clean label by copying information from product labels of other manufacturers. There was a "safety data sheet" that outlined the hazardous ingredients in Sun-Clean, but Mr. Morgan ignored it. The sheet indicated that Sun-Clean contained a caustic soda, but the Sun-Clean label stated that the product contained no caustics. The data sheet also warned "Danger...Avoid breathing vapor. Keep container closed. Use with adequate ventilation." The Sun-Clean label, however, did not warn against breathing Sun-Clean vapors. Furthermore, Mr. 
Morgan did not submit either the label or the product to OSHA for approval, as required by federal regulations. Nor did Mr. Morgan consult "OSHA operating standards" to determine whether the product met those standards. Mr. Morgan simply copied the OSHA label from another label and placed it on his in order to keep costs to a minimum. A chemist employed by Mr. Morgan had the responsibility to review labels. He did not recommend any label changes.

Mrs. Herman's attorneys are seeking $\$ 18,546$ in past medical expenses, $\$ 20,000$ for future medical expenses, $\$ 5000$ for lost wages, and $\$ 120,000$ for future wage losses due to the inability to work full-time. In addition, they are seeking $\$ 500,000$ for pain and suffering. follows:

When presented with this case, Morgan Chemicals (Mr. Morgan) responded as

Concession: Our company (I) sincerely apologizes for the injuries suffered by Mrs. Herman. It was our responsibility to ensure that our products contained the proper safety labels and that our employees were instructed on the safe use of those products. We realize that neglecting to meet those responsibilities resulted in harm to Mrs. Herman and we are truly sorry. We have developed a new labeling procedure and are taking extensive precautions to ensure that this incident is not repeated.

Excuse: I am truly sorry that Mrs. Herman became ill after demonstrating my product. The chemist who is responsible for checking the safety label was going through a difficult divorce. As a result, he was suffering from severe depression which required hospitalization shortly after this product was labeled. The depression interfered with his ability to think clearly, resulting in a mistake when reading the safety sheet. As a result, the chemist failed to ensure the correct labeling of the product.

Justification: Our company truly regrets that Mrs. Herman became ill after demonstrating our products. However, our company performed internal research which showed that the chemicals in our products were not dangerous. Therefore, we did not feel that there was any need to warn of possible dangers.

Refusal: Our company (I) does not feel that Mrs. Herman's illness is the fault of our company, nor do we feel that we could have prevented her illness. We have numerous other employees who demonstrate and none of them have reported any health problems. We are sympathetic to Mrs. Herman, but we do not believe that her illness is in any way related to our product or her employment with our company. 
Judge's Instructions: I will now instruct you on the law you must follow in reaching your decision. In a prior judicial hearing, the defendant (defendant's name) was determined to be liable (at fault) for negligence in failing to adequately warn of the dangers associated with use of its product, Sun-Clean. Therefore, you will not have to determine which party was a fault. Your task will be to award damages to the plaintiff, (plaintiff's name).

Please consider, how you, as a juror, might decide this civil case. Of course, in a real trial, you would have much more information. However, based just on the limited information that you have received, please answer the following questions about the lawsuit against (defendant).

The defendant has been found liable for the injuries sustained by (plaintiff). The Court's determination that the defendant was negligent should not influence your damage award determinations.

It is now your responsibility to award (plaintiff) such sum as you find will fairly and justly compensate him for any damages he sustained as a direct result of the defendant's negligence. The sole purpose of these damages is to make (plaintiff) whole again or return him to his state prior to the accident. This type of damages is not to be used to punish the defendant. For this reason, you may consider only the extent of (plaintiff's) needs and injuries and how these injuries will affect the remainder of his life. You may not take into consideration any characteristics of the defendant.

a) medical expenses

b) loss of wages

(or consortium)

c) pain and suffering (amount in numbers)

(amount in numbers)

(amount in numbers) (amount in words)

(amount in words)

(amount in words)

In addition to any damages which you find (plaintiff) entitled, you may, but are not required to, award (plaintiff) an additional amount as punitive damages if you find it is appropriate to punish the defendant or to deter defendant and others from like conduct in the future. Whether to award plaintiff punitive damages, and the amount of those damages, are within your discretion. This type of damages is meant to punish and deter and in making this award, you may take into account conduct and characteristics of the defendant. However, the purpose of these damages is not to further compensate the plaintiff so you should not consider the plaintiff's needs or injuries.

Punitive Award

(amount in numbers)

(amount in words) 


\section{Appendix C}

\section{Please respond to the following statements to the best of your ability by circling the number that best reflects your opinion.}

1. The plaintiff's life will never be the same as a result of this incident.

$\begin{array}{lllllllllll}\begin{array}{l}\text { Strongly } \\ \text { Agree }\end{array} & 1 & 2 & 3 & 4 & 5 & 6 & 7 & 8 & 9 & \text { Strongly } \\ \text { Disagree }\end{array}$

2. The defendant truly regrets his behavior.

$\begin{array}{llllllllllll}\begin{array}{l}\text { Strongly } \\ \text { Agree }\end{array} & 1 & 2 & 3 & 4 & 5 & 6 & 7 & 8 & 9 & \begin{array}{l}\text { Strongly } \\ \text { Disagree }\end{array}\end{array}$

3. The defendant's behavior was reckless.

$\begin{array}{lllllllllll}\begin{array}{l}\text { Strongly } \\ \text { Agree }\end{array} & 1 & 2 & 3 & 4 & 5 & 6 & 7 & 8 & 9 & \begin{array}{l}\text { Strongly } \\ \text { Disagree }\end{array}\end{array}$

4. The degree of pain and suffering on the part of the plaintiff was minimal.

$\begin{array}{lllllllllll}\begin{array}{l}\text { Strongly } \\ \text { Agree }\end{array} & 1 & 2 & 3 & 4 & 5 & 6 & 7 & 8 & 9 & \begin{array}{l}\text { Strongly } \\ \text { Disagree }\end{array}\end{array}$

5. The defendant acted in this manner knowing that harm would occur.

$\begin{array}{lllllllllll}\begin{array}{l}\text { Strongly } \\ \text { Agree }\end{array} & 1 & 2 & 3 & 4 & 5 & 6 & 7 & 8 & 9 & \begin{array}{l}\text { Strongly } \\ \text { Disagree }\end{array}\end{array}$

6. The necessary precautions to prevent this type of incident were taken.

$\begin{array}{lllllllllll}\begin{array}{l}\text { Strongly } \\ \text { Agree }\end{array} & 1 & 2 & 3 & 4 & 5 & 6 & 7 & 8 & 9 & \begin{array}{l}\text { Strongly } \\ \text { Disagree }\end{array} \\ \end{array}$

7. The defendant appears to regret his actions.

$\begin{array}{lllllllllll}\begin{array}{l}\text { Strongly } \\ \text { Agree }\end{array} & 1 & 2 & 3 & 4 & 5 & 6 & 7 & 8 & 9 & \begin{array}{l}\text { Strongly } \\ \text { Disagree }\end{array}\end{array}$

8. A damage award will cause financial hardship for the defendant.

$\begin{array}{lllllllllll}\begin{array}{l}\text { Strongly } \\ \text { Agree }\end{array} & 1 & 2 & 3 & 4 & 5 & 6 & 7 & 8 & 9 & \begin{array}{l}\text { Strongly } \\ \text { Disagree }\end{array}\end{array}$

9. The plaintiff's injuries were not severe.

$\begin{array}{lllllllllll}\begin{array}{l}\text { Strongly } \\ \text { Agree }\end{array} & 1 & 2 & 3 & 4 & 5 & 6 & 7 & 8 & 9 & \begin{array}{l}\text { Strongly } \\ \text { Disagree }\end{array}\end{array}$

10. The defendant should have no difficulty paying an amount awarded against him.

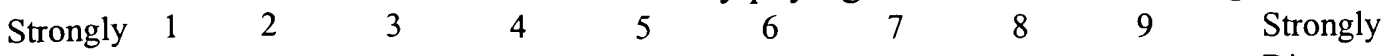
Agree $\quad$ Disagree

11. The defendant accepted responsibility for his actions.

$\begin{array}{lllllllllll}\begin{array}{l}\text { Strongly } \\ \text { Agree }\end{array} & 1 & 2 & 3 & 4 & 5 & 6 & 7 & 8 & 9 & \begin{array}{l}\text { Strongly } \\ \text { Disagree }\end{array}\end{array}$




\section{Appendix D}

Please answer the following demographic questions.

12. Sex: Male

13. Race:

White/Non-Hispanic

Female

White/Hispanic

14. Age: $18-29$

30-39

50-59

Hispanic/Black

40-49

$60+$

Black

Other

15. Marital Status: 1. never married

2. divorced

3. married

4. widow/ widower

16. Education Level 1. less than high school graduate

2. high school graduate

3. some college

4. college degree

5. post-graduate college work or degree

17. Employment Status: 1. Full-Time

3. Retired

2. Part-Time

4. Unemployed

18. Occupation:

19. Aside from your political affiliation, how would you evaluate your political views?

1. Liberal

3. Somewhat conservative

2. Somewhat liberal

4. Conservative

20. Please indicate your annual family income.

$\begin{array}{lr}\text { under } \$ 15,000 & \$ 15,001-\$ 30,000 \\ \$ 45,001-\$ 60,000 \_ & \$ 60,001-\$ 70,000\end{array}$

$\$ 30,001-\$ 45,000$

Above $\$ 71,000$

21. Have you ever served on a civil or criminal jury?

1. Yes, Civil

2. Yes, Criminal

3. No, Never

22. Have you ever been a party in a lawsuit?

1. Yes, I have sued someone

2. Yes, I have been sued

3. Yes, I have both sued someone and been sued

4. No, I have never been involved 
Table E1

Mean Economic Damage Awards (in dollars) as a function of Defendant Status,

Defendant Reprehensibility, and Account Proffered

Defendant Reprehensibility

\begin{tabular}{|c|c|c|c|c|}
\hline Account & Defendant Status & & Low & High \\
\hline \multirow[t]{4}{*}{ Concessions } & Individual & $\underline{\mathrm{M}}$ & 85,295 & 100,946 \\
\hline & & $\underline{\mathrm{SD}}$ & 19,688 & 20,379 \\
\hline & Corporate & $\underline{\mathrm{M}}$ & 120,040 & 98,143 \\
\hline & & $\underline{\mathrm{SD}}$ & 19,378 & 20,037 \\
\hline \multirow[t]{4}{*}{ Excuses } & Individual & $\underline{\mathrm{M}}$ & 125,276 & 93,423 \\
\hline & & $\underline{\mathrm{SD}}$ & 19,688 & 20,036 \\
\hline & Corporate & $\underline{\mathrm{M}}$ & 94,213 & 104,430 \\
\hline & & $\underline{\mathrm{SD}}$ & 20,431 & 19,688 \\
\hline \multirow[t]{4}{*}{ Justifications } & Individual & $\underline{\mathrm{M}}$ & 91,536 & 157,384 \\
\hline & & $\underline{\mathrm{SD}}$ & 19,688 & 20,431 \\
\hline & Corporate & $\underline{\mathrm{M}}$ & 109,489 & 97,454 \\
\hline & & $\underline{\mathrm{SD}}$ & 19,688 & 20,037 \\
\hline \multirow[t]{4}{*}{ Refusals } & Individual & $\underline{\mathrm{M}}$ & 115,282 & 82,724 \\
\hline & & $\underline{\mathrm{SD}}$ & 20,037 & 20,036 \\
\hline & Corporate & $\underline{\mathrm{M}}$ & 164,393 & 117,639 \\
\hline & & $\underline{\mathrm{SD}}$ & 18,991 & 20,037 \\
\hline
\end{tabular}


Table E2

Mean Pain and Suffering Damage Awards (in dollars) as a function of Defendant Status and Account Proffered

\section{Defendant Status}

\begin{tabular}{llrr} 
Account & & Individual & Corporate \\
\hline Concessions & $\underline{\mathrm{M}}$ & 382,631 & 433,385 \\
& $\underline{\mathrm{SD}}$ & 38,463 & 38,136 \\
Excuses & $\underline{\mathrm{M}}$ & 436,161 & 375,080 \\
& $\underline{\mathrm{SD}}$ & 37,806 & 38,513 \\
Justifications & $\underline{\mathrm{M}}$ & 394,671 & 389,835 \\
& $\underline{\mathrm{SD}}$ & 39,270 & 38,136 \\
Refusals & $\underline{\mathrm{M}}$ & 376,244 & 437,425 \\
& $\underline{\mathrm{SD}}$ & 38,136 & 37,542 \\
\hline
\end{tabular}


Table E3

Mean Pain and Suffering Damage Awards (in dollars) as a function of Defendant Status,

Defendant Reprehensibility, and Account Proffered

Defendant Reprehensibility

\begin{tabular}{|c|c|c|c|c|}
\hline Account & Defendant Status & & Low & High \\
\hline \multirow[t]{4}{*}{ Concessions } & Individual & $\underline{M}$ & 353,833 & 411,429 \\
\hline & & $\underline{\mathrm{SD}}$ & 53,932 & 54,854 \\
\hline & Corporate & $\underline{\mathrm{M}}$ & 423,341 & 443,428 \\
\hline & & $\underline{\mathrm{SD}}$ & 53,932 & 53,932 \\
\hline \multirow[t]{4}{*}{ Excuses } & Individual & $\underline{\mathrm{M}}$ & 463,889 & 408,433 \\
\hline & & $\underline{\mathrm{SD}}$ & 52,994 & 53,932 \\
\hline & Corporate & $\underline{\mathrm{M}}$ & 312,327 & 437,833 \\
\hline & & $\underline{\mathrm{SD}}$ & 55,899 & 52,994 \\
\hline \multirow[t]{4}{*}{ Justifications } & Individual & $\underline{\mathrm{M}}$ & 348,052 & 441,390 \\
\hline & & $\underline{\mathrm{SD}}$ & 53,932 & 57,094 \\
\hline & Corporate & $\underline{\mathrm{M}}$ & 393,385 & 386,286 \\
\hline & & $\underline{\mathrm{SD}}$ & 53,932 & 53,932 \\
\hline \multirow[t]{4}{*}{ Refusals } & Individual & $\underline{\mathrm{M}}$ & 432,957 & 319,532 \\
\hline & & $\underline{\mathrm{SD}}$ & 53,932 & 53,932 \\
\hline & Corporate & $\underline{\mathrm{M}}$ & 392,894 & 481,956 \\
\hline & & $\underline{\mathrm{SD}}$ & 52,238 & 53,932 \\
\hline
\end{tabular}


Table E4

Mean Economic Damage Awards (in dollars) as a function of Defendant Status, Account

Proffered, and Negligence Stipulation

Negligence Stipulation

\begin{tabular}{lllll}
$\begin{array}{l}\text { Defendant } \\
\text { Status }\end{array}$ & Account & & No Stipulation & Stipulation \\
\hline Individual & Concession & $\underline{\mathrm{M}}$ & 65,680 & 87,777 \\
& & $\underline{\mathrm{SD}}$ & 17,828 & 17,262 \\
& Excuse & $\underline{\mathrm{M}}$ & 95,078 & 64,726 \\
& & $\underline{\mathrm{SD}}$ & 17,828 & 17,828 \\
Corporate & Concession & $\underline{\mathrm{M}}$ & 135,488 & 70,818 \\
& & $\underline{\mathrm{SD}}$ & 17,262 & 18,453 \\
& & $\underline{\mathrm{M}}$ & 75,910 & 71,361 \\
& Excuse & $\underline{\mathrm{SD}}$ & 19,150 & 17,828 \\
\hline
\end{tabular}


Table E5

Mean Pain and Suffering Damage Awards (in dollars) as a function of Defendant Status and Account Proffered

Defendant Status

\begin{tabular}{llcr} 
Account & & Individual & Corporate \\
\hline Concessions & $\underline{\mathrm{M}}$ & 206,198 & 389,964 \\
& $\underline{\mathrm{SD}}$ & 34,360 & 35,384 \\
Excuses & $\underline{\mathrm{M}}$ & 236,722 & 186,738 \\
& $\underline{\mathrm{SD}}$ & 34,184 & 35,475 \\
\hline
\end{tabular}

Table E6

Mean Pain and Suffering Damage Awards (in dollars) as function of Defendant Status and Negligence Stipulation

Negligence Stipulation

Defendant

No Stipulation

Stipulation

Status

\begin{tabular}{lrrr}
\hline Individual & $\underline{\mathrm{M}}$ & 235,833 & 207,087 \\
& $\underline{\mathrm{SD}}$ & 34,789 & 33,646 \\
Corporate & $\underline{\mathrm{M}}$ & 282,113 & 294,590 \\
& $\underline{\mathrm{SD}}$ & 36,058 & 34,789 \\
\hline
\end{tabular}


Table E7

Mean Pain and Suffering Damage Awards (in dollars) as a function of Account Proffered and Negligence Stipulation

\section{Negligence Stipulation}

\begin{tabular}{lrrr} 
Account & & No Stipulation & Stipulation \\
\hline Concession & $\underline{\mathrm{M}}$ & 317,286 & \\
& $\underline{\mathrm{SD}}$ & 35,384 & 278,877 \\
\multirow{2}{*}{ Excuse } & $\underline{\mathrm{M}}$ & 200,660 & 22,260 \\
& $\underline{\mathrm{SD}}$ & 35,475 & 34,184 \\
\hline
\end{tabular}


B.S., Psychology

Arkansas State University

Jonesboro, Arkansas

1997-2000

\author{
M.S., Psychology \\ Florida International University \\ Miami, Florida \\ Teaching Assistant \\ Florida International University \\ Miami, Florida
}

Doctoral Candidate in Psychology

Florida International University

Miami, Florida

Psychology Instructor

Florida International University

Miami, Florida

\title{
PRESENTATIONS
}

Carpenter, T. R., Kovera, M. B., \& Moran, G. (2000, March). Countering the effects of extra-legal factors in damage award decisions. Poster session presented at the biennial meeting of the American Psychology-Law Society, New Orleans, LA. 